\title{
Expression of the P2Y, Nucleotide Receptor in Chick Muscle: Its Functional Role in the Regulation of Acetylcholinesterase and Acetylcholine Receptor
}

\author{
Roy C. Y. Choi, ${ }^{1}$ Menlisa L. S. Man, ${ }^{1}$ Karen K. Y. Ling, ${ }^{1}$ Nancy Y. Ip, ${ }^{2}$ Joseph Simon, ${ }^{3}$ Eric A. Barnard, ${ }^{3}$ and \\ Karl W. K. Tsim ${ }^{1}$ \\ Departments of ${ }^{1}$ Biology and ${ }^{2}$ Biochemistry, Molecular Neuroscience Center and Biotechnology Research Institute, Hong \\ Kong University of Science and Technology, Hong Kong, China, and ${ }^{3}$ Department of Pharmacology, University of \\ Cambridge, Cambridge CB2 1QJ, United Kingdom
}

In vertebrate neuromuscular junctions, ATP is stored at the motor nerve terminals and is co-released with acetylcholine during neural stimulation. Here, we provide several lines of evidence that the synaptic ATP can act as a synapse-organizing factor to induce the expression of acetylcholinesterase (AChE) and acetylcholine receptor (AChR) in muscles, mediated by a metabotropic ATP receptor subtype, the $\mathrm{P}_{2} \mathrm{Y}_{1}$ receptor. The activation of the $\mathrm{P}_{2} \mathrm{Y}_{1}$ receptor by adenine nucleotides stimulated the accumulation of inositol phosphates and intracellular $\mathrm{Ca}^{2+}$ mobilization in cultured chick myotubes. $\mathrm{P}_{2} \mathrm{Y}_{1}$ receptor mRNA in chicken muscle is very abundant before hatching and again increases in the adult. The $\mathrm{P}_{2} \mathrm{Y}_{1}$ receptor protein is shown to be restricted to the neuromuscular junctions and colocalized with AChRs in adult muscle (chicken, Xenopus, and rat) but not in the chick embryo. In chicks after hatching, this P2Y 1 localization develops over $\sim 3$ weeks. Denervation or crush of the motor nerve (in chicken or rat) caused up to $90 \%$ decrease in the muscle $\mathrm{P}_{2} \mathrm{Y}_{1}$ transcript, which was restored on regeneration, whereas the AChR mRNA greatly increased. Last, mRNAs encoding the AChE catalytic subunit and the AChR $\alpha$-subunit were induced when the $\mathrm{P}_{2} \mathrm{Y}_{1}$ receptors were activated by specific agonists or by overexpression of $\mathrm{P}_{2} \mathrm{Y}_{1}$ receptors in cultured myotubes; those agonists likewise induced the activity in the myotubes of promoter-reporter gene constructs for those subunits, actions that were blocked by a P2Y specific antagonist. These results provide evidence for a novel function of ATP in regulating the gene expression of those two postsynaptic effectors.

Key words: ATP receptors; $P 2 Y_{1}$ receptor; neuromuscular junction; trophic factors; acetylcholine receptor gene regulation; acetylcholinesterase gene regulation; chick muscle
In vertebrate neuromuscular junctions, acetylcholine receptors (AChRs) and collagen-tailed acetylcholinesterase (AChE) become localized and densely clustered, although the mechanisms and interactions (Duclert and Changeux, 1995; Krejci et al., 1999; Sanes and Lichtman, 1999) that are involved are different. For $\mathrm{AChR}$ in muscle, also, biosynthesis is regulated by nerve-derived factors, which include calcitonin gene-related peptide (CGRP) (New and Mudge, 1986; Fontaine et al., 1987), ascorbic acid (Horovitz et al., 1989), and neuregulin (Sandrock et al., 1997). Simultaneously, the nerve evokes muscle cell electrical activity that suppresses AChR synthesis in the extrasynaptic regions (Duclert and Changeux, 1995); hence, focalization of AChRs at the synapse occurs.

ATP is an additional potential trophic factor for endplates. ATP is co-stored in and constantly co-released quantally with

\footnotetext{
Received April 26, 2001; revised Sept. 6, 2001; accepted Sept. 12, 2001.

This work was supported by grants from the Research Grants Council of Hong Kong [Hong Kong University of Science and Technology (HKUST) 6099/98M, 6112/00M, and 2/99C] and Biotechnology Research Institute at HKUST (K.W.K.T.) and from the Wellcome Trust (E.A.B.). We thank Drs. Kathy Luo, Donald Chang, and Fanny Ip from HKUST for discussion and assistance with this work, and Dr. J. Sanes of Washington University (St. Louis, MO) and Prof. H. Soreq of The Hebrew University of Jerusalem (Jerusalem, Israel) for providing AChR $\alpha$-subunit and AChE promoter DNAs.

R.C.Y.C. and M.L.S.M. contributed equally to this study.

Correspondence should be addressed to Dr. Karl W. K. Tsim, Department of Biology, The Hong Kong University of Science and Technology, Clear Water Bay Road, Hong Kong, China. E-mail: botsim@ust.hk.

Copyright (C) 2001 Society for Neuroscience $0270-6474 / 01 / 219224-11 \$ 15.00 / 0$
}

acetylcholine (in a ratio of $\sim 1: 6$ ) from the nerve terminals in vertebrate skeletal muscles (Silinsky and Redman, 1996) or electroplaques (Israel and Dunant, 1998). The action of released ATP would be confined locally by its subsequent hydrolysis to adenosine by ectonucleotidases (Redman and Silinsky, 1994; Zimmermann, 1999). Receptors for extracellular ATP (P2 receptors) would become activated if present at or near the junctions. P2 receptors are nucleotide receptors, either ionotropic $(\mathrm{P} 2 \mathrm{X})$ or G-protein coupled (P2Y) (North and Barnard, 1997; Ralevic and Burnstock, 1998). Nine P2Y subtypes (of varying nucleotide agonist specificities) in mammals and birds are known by cloning and expression, although species ortholog are not always clear (Barnard and Simon, 2001).

Indeed, earlier studies have suggested that ATP could exert effects on neuromuscular transmission. In skeletal muscles, exogenous ATP can potentiate responses to acetylcholine (Ewald, 1976; Akasu et al., 1981; Lu and Smith, 1991). In Xenopus embryonic nerve-muscle cocultures, focal application of ATP increased spontaneous synaptic currents, whereas on myocytes it potentiated the response to acetylcholine (Fu et al., 1997). These ATP-induced effects were blocked by general antagonists for P2 receptors and by protein kinase $\mathrm{C}$ (PKC) inhibitors and were not caused by adenosine receptors ( $\mathrm{Lu}$ and Smith, 1991; Fu et al., 1997). Pharmacological and patch-clamp evidence on those responses to ATP on chick and mammalian muscle cells (Häggblad and Heilbronn, 1988; Lu and Smith, 1991; Fu et al., 1997; Henning, 1997) generally correspond to the now-known P2Y class of 
receptors. However, ion channels directly opened by ATP are also detectable on embryonic muscle cells from chicken (Kolb and Wakelam, 1983; Thomas et al., 1991) and mammals (for review, see Henning, 1997). Possible trophic effects in muscles of ATP mediated by either $\mathrm{P} 2 \mathrm{Y}$ or $\mathrm{P} 2 \mathrm{X}$ receptors now merit consideration.

Here we have examined actions of nucleotides on skeletal muscle cells in terms of current molecular knowledge of P2 receptors. In chick myotubes, the signaling responses showed a major contribution of the $\mathrm{P} 2 \mathrm{Y}_{1}$ receptor subtype. In chicken and rat muscle, the expression and development of $\mathrm{P} 2 \mathrm{Y}_{1}$ receptors and their localization in relation to the neuromuscular junctions were demonstrated. Further results support a novel function of synaptic ATP and its activation of $\mathrm{P}_{2} \mathrm{Y}_{1}$ receptors in the regulation of gene expression of postsynaptic AChR and AChE.

\section{MATERIALS AND METHODS}

Materials. Cell culture media, fetal calf or horse sera, and other cell culture reagents were from Life Technologies (Grand Island, NY). UTP and UDP were ultra-pure grade from Amersham Pharmacia Biotech (Little Chalfont, UK). Other P2Y receptor agonists and antagonists were the purest grades available from either Research Biochemicals International (Natick, MA) or Sigma (St. Louis, MO). These included adenosine 3'-5'-bismonophosphate (sodium salt; A3P5P), ATP (disodium salt), ADP (sodium salt), $\alpha, \beta$-methyleneadenosine 5 '-triphosphate (lithium salt; $\alpha \beta$-meATP), 2-methylthioadenosine $5^{\prime}$-triphosphate (tetrasodium salt; 2-MeSATP), 2-methylthioadenosine diphosphate (trisodium salt; 2-MeSADP), pyridoxal-phosphate-6-azophenyl-2' 4'-disulfonic acid (tetrasodium salt; PPADS), Reactive blue 2 (RB-2), and suramin. The commercial antibodies were purchased from Sigma or Cappel (Durham, $\mathrm{NC}$ ), and tetramethylrhodamine-conjugated- $\alpha$-bungarotoxin (TMRBuTX) was from Molecular Probes (Eugene, OR). Radiochemicals were from Amersham Pharmacia Biotech. Apyrase (Grade V II) was also from Sigma, and other reagents of unspecified source were analytical grades.

Purity of nucleotides. ADP, 2-MeSADP, and UDP stock solutions (1 $\mathrm{mM}$ ) were preincubated with $20 \mathrm{U} / \mathrm{ml}$ yeast hexokinase (Roche Biochemicals, Lewes, UK) in Buffer A (2.5 mM $\mathrm{MgCl}_{2} / 50 \mathrm{~mm}$ HEPES, pH 7.3) containing $25 \mathrm{~mm}$ glucose at $37^{\circ} \mathrm{C}$ for $30 \mathrm{~min}$ ( $90 \mathrm{~min}$ for UDP) to remove all contaminating triphosphates (Boyer et al., 1996). ATP and 2-MeSATP stock solutions (1 mM) were pretreated in Buffer A with 20 $\mathrm{U} / \mathrm{ml}$ creatine phosphokinase (CPK; Sigma) and $10 \mathrm{~mm}$ creatine phosphate (CP; Sigma) at room temperature for $90 \mathrm{~min}$ to remove all contaminating diphosphates, as described and validated elsewhere (Simon et al., 2001). UTP $(10 \mathrm{~mm})$ was treated similarly but for $3 \mathrm{hr}$ and with $\mathrm{CP}$ at $50 \mathrm{~mm}$, because of its higher $K_{\mathrm{m}}$ and lower $V_{\text {max. }}$ During the incubations for the inositol phosphate assays and for the stimulation of myotube expression of AChE/AChR or promoter activity, when triphosphate agonists were used CPK was also present throughout at $2 \mathrm{U} / \mathrm{ml}, \mathrm{CP}$ at $5 \mathrm{~mm}$, and $\mathrm{Mg}^{2+}$ at $2.5 \mathrm{~mm}$. When diphosphate agonists were used, hexokinase was present at $2 \mathrm{U} / \mathrm{ml}$, glucose at $5 \mathrm{~mm}$, and $\mathrm{Mg}^{2+}$ at $2.5 \mathrm{~mm}$. Those media used alone in the control incubations in each case had no effect. For the longer incubations with an agonist, renewals at intervals of the agonist and that medium were also made, as stated.

Animals. Pectoral muscles of New Hampshire chickens at the stated ages were collected immediately after chickens were killed, frozen in liquid nitrogen, and stored at $-80^{\circ} \mathrm{C}$ for total RNA extraction. For reversible denervation, post-hatch day $(\mathrm{P}) 18$ chicks or adult rats $(\sim 300$ $\mathrm{gm}$ ) were fully anesthetized with isoflurane, and $\sim 5 \mathrm{~mm}$ of the left sciatic nerve was removed using aseptic surgical technique (Ip et al., 1996). Gastrocnemius muscle of the operated side was collected immediately after the animal was killed at the indicated time points after the surgery, frozen in liquid nitrogen, and stored at $-80^{\circ} \mathrm{C}$. Nerve crush was performed with a prechilled fine forceps on the left sciatic nerve in the upper thigh of chicks or rats, and the gastrocnemius muscles were collected similarly. All procedures conformed to the Guidelines by Animal Research Panel of Hong Kong University of Science and Technology for the use and care of laboratory animals in research.

Cell cultures. Primary chick myotube cultures were prepared from hindlimb muscles dissected from 11-d-old chick embryos as described previously (Fischbach, 1972; modified by Tsim et al., 1992). The muscle cells were cultured in Eagle's MEM supplemented with $10 \%$ heatinactivated horse serum, $2 \%(\mathrm{v} / \mathrm{v})$ chick embryo extract, $1 \mathrm{~mm}$
L-glutamine, $100 \mathrm{U} / \mathrm{ml}$ penicillin, and $100 \mu \mathrm{g} / \mathrm{ml}$ streptomycin. The cultures were then incubated at $37^{\circ} \mathrm{C}$ in a water-saturated $5 \% \mathrm{CO}_{2}$ atmosphere. Myotubes were treated with a mitotic inhibitor $(10 \mu \mathrm{M}$ cytosine arabinoside) at day 3 after plating and used on day 4. COS-7 cells were cultured in $100 \mathrm{~mm}$ culture dishes in DMEM with $10 \%$ fetal calf serum, $100 \mathrm{U} / \mathrm{ml}$ penicillin, and $100 \mu \mathrm{g} / \mathrm{ml}$ streptomycin at $37^{\circ} \mathrm{C}$ in a humidified atmosphere of $5 \% \mathrm{CO}_{2}$. Because skeletal muscle cell cultures can release some ATP into the medium and can also convert it there to ADP, and because over longer periods these agents may give some desensitization of $\mathrm{P} 2 \mathrm{Y}$ receptors, they were pretreated with apyrase (2 $\mathrm{U} / \mathrm{ml})$ for $1 \mathrm{hr}$ or when loading with $\left[{ }^{3} \mathrm{H}\right]$ myoinositol $(24 \mathrm{hr})$ to eliminate all such free nucleotides, before a gentle wash and drug application in apyrase-free medium.

Inositol phosphate and cAMP accumulation assays. Inositol-free DMEM $(750 \mu \mathrm{l})$, containing $10 \%$ horse serum and $2.5 \mu \mathrm{Ci} / \mathrm{ml}\left[{ }^{3} \mathrm{H}\right] \mathrm{my}-$ oinositol and apyrase $(2 \mathrm{U} / \mathrm{ml})$ to prevent desensitization by released nucleotides, was added to cultured myotubes and incubated $24 \mathrm{hr}$. The labeled media were subsequently replaced by $1 \mathrm{ml}$ of inositol phosphate assay medium (DMEM buffered with $20 \mathrm{mM}$ HEPES, pH 7.5) with apyrase also present at $0.2 \mathrm{U} / \mathrm{ml}$ and further incubated $1 \mathrm{hr}$ to reduce basal inositol phosphate level. The media were then replaced by fresh inositol phosphate assay medium, apyrase-free but with the usual inositol phosphatase inhibitor $\mathrm{LiCl}(20 \mathrm{~mm})$ present, and incubated for a further $10 \mathrm{~min}$. After one gentle replacement by the same medium, the appropriate agonists were applied in a final volume of $1 \mathrm{ml}$, and the cells were incubated at $37^{\circ} \mathrm{C}$ for $30 \mathrm{~min}$. In these assays the medium also contained the protective enzyme mixture as noted above. Reactions were then stopped by the addition of $750 \mu \mathrm{l}$ of ice-cold $20 \mathrm{~mm}$ formic acid and held at $4^{\circ} \mathrm{C}$ for $1 \mathrm{hr}$. The total $\left[{ }^{3} \mathrm{H}\right]$ inositol phosphates were separated from other labeled inositol species by sequential ion-exchange chromatography as described previously (Tsu et al., 1995). cAMP assays were performed as described previously (Choi et al., 1998). Briefly, 4-d-old myotube cultures were prelabeled for $16-20 \mathrm{hr}$ with $\left[2-{ }^{3} \mathrm{H}\right]$ adenine $(1 \mu \mathrm{Ci} / \mathrm{ml})$ and treated with agonist. The reaction was stopped by addition of $5 \%$ trichloroacetic acid containing $1 \mathrm{mM}$ ATP, and the $\left[{ }^{3} \mathrm{H}\right] \mathrm{cAMP}$ fraction was isolated via Dowex and alumina columns. The $\left[{ }^{3} \mathrm{H}\right] \mathrm{cAMP}$ accumulation was expressed as a percentage of that present (basal) before nucleotide addition.

Calcium imaging. Myotubes were grown at $37^{\circ} \mathrm{C}$ on 25 -mm-diameter coverslips, incubated with apyrase $(2 \mathrm{U} / \mathrm{ml}, 1 \mathrm{hr})$, and gently washed with culture medium. The calcium-indicator dye, calcium green-1 conjugated to $10 \mathrm{kDa}$ dextran (Molecular Probes), together with heparin $(5 \mathrm{mg} / \mathrm{ml})$ where stated, was loaded into them by electroporation $(1.1 \mathrm{kV} / \mathrm{cm}$ electroporation intensity, $2 \mathrm{msec}$ pulse width, and 10 pulses per train) (Chang, 1997). During the recovery period, apyrase $(2 \mathrm{U} / \mathrm{ml})$ was again present. After 2-3 hr incubation, each coverslip was washed and transferred in culture medium to a temperature $\left(37^{\circ} \mathrm{C}\right)$-controlled microincubation chamber mounted on the stage of a Zeiss Axiovert 35 microscope. With excitation at $488 \mathrm{~nm}$, the calcium green-1 fluorescence images were recorded at $529 \mathrm{~nm}$ using a digital imaging system with a cooled CCD camera (MicroMax, Princeton Instruments, Trenton, NJ) and MetaMorph Image-processing software v3.0 (Universal Imaging, Hollis, NH), and ligand was applied as stated. The calibration curve relating calcium concentration to the fluorescence intensity was determined and used according to a previously described method (Kao, 1994).

Microphysiometry. Functional assays using microphysiometry were performed according to the methods of Pitchford et al. (1995). Briefly, 5-d-old cultured chick myotubes in capsules were transferred to microphysiometer sensor chambers (Cytosensor; Molecular Devices, Sunnyvale, CA) at $37^{\circ} \mathrm{C}$ and equilibrated by perfusion for $2 \mathrm{hr}$ in running medium (DMEM supplemented with $0.1 \%$ bovine serum albumin, adjusted with $\mathrm{NaOH}$ to $\mathrm{pH} 7.38$ ). When stable acidification rates were established thus, cells were exposed for 6 min to various agents in the running medium at a flow rate of $100 \mu \mathrm{l} / \mathrm{min}$. The acidification rates were measured at 2 min intervals. The $\mathrm{pH}$ changes were converted by the sensor computer program to $\mathrm{H}^{+}$ion output from the cells.

Northern blots. Total RNA was prepared from the tissues or cells using the $\mathrm{LiCl}$ method (Sambrook et al., 1989), and the RNA samples were electrophoresed through a $1 \%$ formaldehyde gel. RNA concentration and purity were determined by UV spectrometry, and a nominal loading of $30 \mu \mathrm{g}$ per lane was used. After electrophoretic separation, RNA bands were transferred to a charged nylon membrane and were UV crosslinked. Blots were hybridized in turn with the following probes (from within, or spanning all, the coding sequence): $\sim 1.5 \mathrm{~kb}$ chick $\mathrm{P}_{2} \mathrm{Y}_{1}$ receptor cDNA (Webb et al., 1993), $\sim 0.6 \mathrm{~kb}$ from the chick AChE 
catalytic subunit cDNA (Tsim et al., 1992), 1.2 kb from the chick AChR $\alpha$-subunit cDNA (Pun and Tsim, 1997), $\sim 0.5 \mathrm{~kb}$ from the rat $\mathrm{P}_{2} \mathrm{Y}_{1}$ receptor cDNA (Tokuyama et al., 1995) (between bases 930 and 1390), and $\sim 1.9 \mathrm{~kb}$ rat AChR $\alpha$-subunit (Ip et al., 1996). Probes were labeled with $\left[\alpha-{ }^{32} \mathrm{P}\right] \mathrm{dCTP}$; the hybridization was performed at $42^{\circ} \mathrm{C}$ overnight in $40 \%$ deionized formamide, $5 \times$ Denhardt's solution, $0.5 \%$ SDS, $5 \times$ SSC, $10 \%$ dextran sulfate, and $0.1 \mathrm{mg} / \mathrm{ml}$ denatured salmon sperm DNA. After hybridization, filters were washed twice with $2 \times$ SSC with $0.1 \%$ SDS at room temperature for $30 \mathrm{~min}$ each, and then twice with $0.1 \times$ SSC with $0.1 \%$ SDS at $55^{\circ} \mathrm{C}$ for $30 \mathrm{~min}$ each (Sambrook et al., 1989). The filters were then exposed to $\mathrm{x}$-ray film with double intensifying screens at $-80^{\circ} \mathrm{C}$ to suitable intensity. Quantitation was made for samples run on the same gel. On bands scanned on an image analyzer, the relative densities were determined within the linear region of a calibration curve constructed with parallel samples containing ${ }^{32} \mathrm{P}$ microscale standards. Ribosomal RNA was stained with ethidium bromide, and the $28 \mathrm{~S}$ band was quantitated by a parallel method to allow correction for the loading in each lane.

Reporter gene constructs and transfections. The cDNA $(\sim 2.2 \mathrm{~kb})$ encompassing the human AChE promoter (Ben Aziz-Aloya et al., 1993) (a gift from H. Soreq, Hebrew University of Jerusalem) and the $\sim 930 \mathrm{bp}$ chick AChR $\alpha$-subunit promoter region excised from a pnlacZ plasmid (Sanes et al., 1991) (a gift from J. Sanes, Washington University) were subcloned into a pGL3 vector that contained a luciferase gene downstream (Promega, Madison, WI). This resulted in the following reporter gene expression vectors: pAChE-Luc for the human AChE promoter and pAChR $\alpha$-Luc for the chick AChR $\alpha$-subunit promoter. The full-length cDNA encoding the chicken $\mathrm{P}_{2} \mathrm{Y}_{1}$ receptor in a mammalian expression vector, as described previously (Webb et al., 1993; Simon et al., 1995), was cotransfected where stated. Myoblasts from $11 \mathrm{~d}$ chick embryos were cultured for $2 \mathrm{~d}$ and then transfected transiently with the purified plasmids ( $2 \mu \mathrm{g}$ per well in 12 -well plates) by standard calcium precipitation (Pun and Tsim, 1997), and they were allowed to fuse as myotubes. COS-7 cells were transfected by DEAE Dextran method to express the chick $\mathrm{P}_{2} \mathrm{Y}_{1}$ receptor and cultured in their medium (see above) a further $48 \mathrm{hr}$ before use. The transfection efficiency was determined in test cases in which cells were cotransfected with $\beta$-galactosidase cDNA in the same vector, followed by enzymatic staining. The transfection efficiency in myoblasts was consistently from $\sim 15$ to $20 \%$, whereas COS-7 cells showed a transfection efficiency of $>40 \%$.

Western blotting for AChE. Cultured myotubes were collected and homogenized in $10 \mathrm{~mm}$ HEPES, pH 7.5, 0.5\% Triton X-100, $5 \mathrm{~mm}$ EDTA, $5 \mathrm{~mm}$ EGTA, $1 \mathrm{mg} / \mathrm{ml}$ bacitracin, and $1 \mathrm{~m} \mathrm{NaCl}$ and centrif uged at $12,000 \times g$ for $5 \mathrm{~min}$. The supernatant was used for both enzymatic assay and immunoblotting. In immunoblotting, the sample was denatured at $100^{\circ} \mathrm{C}$ for $5 \mathrm{~min}$ in SDS sample buffer, $\mathrm{pH} 7.5$, containing $1 \%$ SDS and $1 \%$ dithiothreitol. The proteins were then separated on a $7.5 \%$ SDSpolyacrylamide gel and electroblotted onto nitrocellulose filters for $16 \mathrm{hr}$ (Tsim et al., 1997). The blot was incubated $\left(1 \mathrm{hr}, 37^{\circ} \mathrm{C}\right)$ with $5 \%$ nonfat dried milk as blocking agent in $20 \mathrm{~mm}$ Tris/137 mM NaCl/0.1\% Tween $20, \mathrm{pH}$ 7.6. After washing in the latter medium alone, purified monoclonal antibody ACB-1 to the chick AChE catalytic subunit (Tsim et al., 1988) $(5-10 \mu \mathrm{g} / \mathrm{ml})$ or anti- $\alpha$-tubulin antibody (1:5000) was applied, followed by peroxidase-conjugated goat anti-mouse $\mathrm{Ig}$ antibody [with procedures as in Tsim et al. (1988)]. The immunoreactive band present in each case was visualized by chemiluminescence according to the ECL protocol (Amersham Pharmacia Biotech) under strictly standardized conditions. The labeling intensities of the protein band from the control and from the agonist-stimulated samples, run in the same gel, were compared by densitometry as for Northern blots in the nonsaturating range of calibration curves constructed with serial dilutions of parallel samples.

Polyclonal antibody against chicken $P 2 Y_{1}$ receptor and labeling of receptors in muscles. A cDNA encoding the thioredoxin protein in the prokaryotic expression vector pET32 (Novagen, Madison, WI) was tagged in-frame at its $5^{\prime}$ end with nucleotides 1143-1417 of the chicken P2Y receptor cDNA sequence as described and numbered in Webb et al. (1993), corresponding to its final C-terminal residues 320-362. That sequence is beyond the last accepted transmembrane domain and has no homology with any other $\mathrm{P} 2 \mathrm{Y}$ receptor. This plasmid was used to transform Escherichia coli strain BL21 (Lys S) to obtain overexpression of the fusion protein. The latter was purified using the Novagen protocol, and rabbits were each immunized three times with it. Antibodies were purified by protein-A affinity chromatography (High Trap column, Amersham Pharmacia Biotech). The polyclonal antibody was used at $\sim 20$
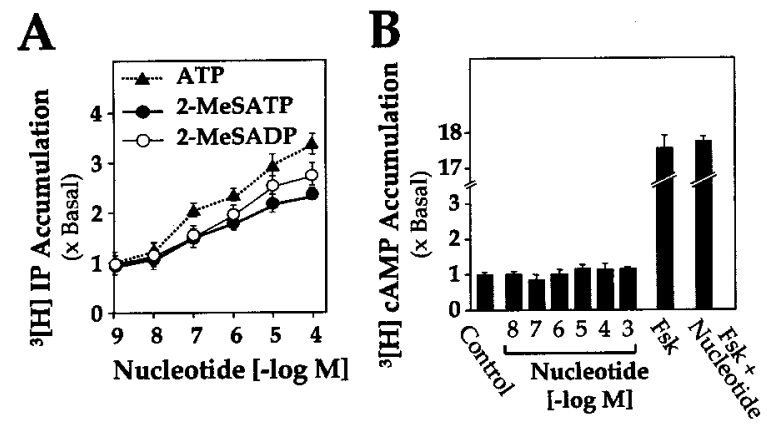

Figure 1. Pharmacological properties of $\mathrm{P} 2 \mathrm{Y}$ receptors in chick muscle cells. Myotubes cultured for $5 \mathrm{~d}$ were pretreated with apyrase, washed, and treated with the indicated concentrations of agonist (or with control medium). Values are expressed as the ratio of the stimulated to the basal level. $A$, ATP or 2-MeSATP or 2-MeSADP induces the accumulation of inositol phosphates $(I P)$. B, ATP or 2-MeSATP or 2-MeSADP does not change the level of intracellular cAMP. The values for all three nucleotides, applied separately, fell within the SEM bars shown. Forskolin (Fsk) at $50 \mu \mathrm{M}$ served as a positive control and also to show that none of these agents decreased a stimulated level of cAMP. In both $A$ and $B$, data are mean \pm SEM values for four independent experiments, each with triplicate samples.

$\mu \mathrm{g} / \mathrm{ml}$ in immunohistochemistry on muscle sections $(20 \mu \mathrm{m})$, with fluorescein-5-isothiocyanate-conjugated goat anti-rabbit Ig second antibody, by methods described elsewhere for other antibodies (Tsim et al., 1997). The sections were double labeled for $\mathrm{P}_{2} \mathrm{Y}_{1}$ receptor thus and for AChR with $10^{-8}$ M TMR-BuTX (Tsim et al., 1997). Staining was viewed under a $20-40 \times$ objective alternately with phase-contrast and fluorescence optics, the latter using excitation at 555 or $488 \mathrm{~nm}$ and emission at 580 or $515 \mathrm{~nm}$ for rhodamine or fluorescein, respectively. To measure percentage colocalization in chick muscle, $\sim 50$ fields were selected at random, and all sites therein that were clearly labeled with either stain and not coinciding with the other stain were taken as not colocalized and compared with the total number of discrete sites seen for both stains. This exaggerates somewhat the colocalization at early stages (up to approximately hatching), where some of the noncoincident staining was too diff use to assign, but the diffuse staining had essentially disappeared after day 4.

Other assays. AChE activity was determined by the Ellman spectroscopic method in a medium containing $0.1 \mathrm{~mm}$ tetraisopropylpyrophosphoramide to inhibit chick butyrylcholinesterase (Tsim et al., 1988). For luciferase assay, the cultures were washed in PBS and resuspended in $0.2 \mathrm{ml}$ lysis buffer $(0.1 \mathrm{M}$ potassium phosphate, $\mathrm{pH} 7.8 / 0.2 \%$ Triton $\mathrm{X}-100 / 1 \mathrm{~mm}$ dithiothreitol). The lysates were then centrifuged at $15,800 \times g$ for $2 \mathrm{~min}$, and the supernatants were used to assay the luciferase activity according to the manufacturer's instructions (Tropix, Bedford, MA). The reaction was quantified on the Tropix TR717 microplate luminometer. Protein concentrations were measured throughout by the method of Bradford (1976).

\section{RESULTS}

\section{Pharmacological properties of $\mathrm{P} 2 \mathrm{Y}$ receptors in chick skeletal muscle cells}

The effects of various agonists or antagonists of $\mathrm{P} 2 \mathrm{Y}$ receptors on second messenger responses were tested in cultured chick myotubes. Included as selective agonists in these and later experiments were 2-MeSATP and 2-MeSADP: the former selects P2Y (Filippov et al., 2000) among all known P2Y receptors, and the latter selects $\mathrm{P} 2 \mathrm{Y}_{1}$ among all known $\mathrm{P} 2 \mathrm{Y}$ and $\mathrm{P} 2 \mathrm{X}$ receptors [the one exception being $\mathrm{P} 2 \mathrm{Y}_{12}$, a platelet receptor unknown in muscle cells and linked to adenylate cyclase inhibition (Barnard and Simon, 2001)], a transduction absent here (Fig. 1B). Chick myotubes were previously known (Häggblad and Heilbronn, 1988) to show an increase in inositol phosphates when treated with ATP, but the P2Y receptors were then unknown and impure ATP was in use. Here, application of purified ATP or 2-MeSATP or 


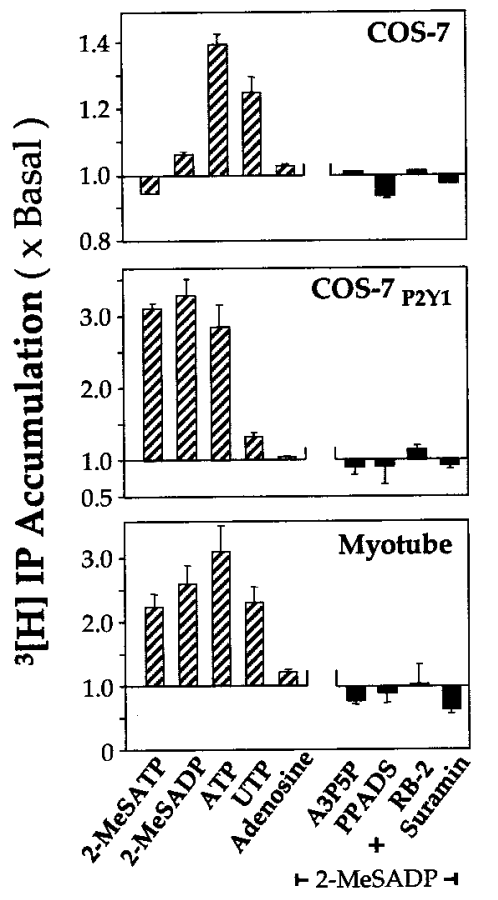

Figure 2. Stimulation of inositol phosphates $(I P)$ accumulation in chick muscle cells or in COS-7 cells expressing the chicken $\mathrm{P}_{2} \mathrm{Y}_{1}$ receptor. The results were obtained and expressed as in Figure $1 A(n=4)$. Left-hand sets of bars: 2-MeSATP $(50 \mu \mathrm{M}), 2-M e S A D P(50 \mu \mathrm{M})$, ATP $(50 \mu \mathrm{M})$, UTP $(50 \mu \mathrm{M})$, and adenosine $(50 \mu \mathrm{M})$ were tested as agonists on myotubes and, for comparison, on COS-7 cells expressing the chicken $\mathrm{P}_{2} \mathrm{Y}_{1}$ receptor $\left(C O S-7_{P 2 Y I}\right)$ cells. Non-transfected COS-7 cells (top panel) show negligible responses to these drugs, except to ATP and UTP, attributable to endogenous $\mathrm{P}_{2} \mathrm{Y}_{2}$-like receptors; these COS-7 cells contain no $\mathrm{P}_{2} \mathrm{Y}_{1}$ receptors. Antagonists tested (right-hand set of bars) were A3P5P $(50 \mu \mathrm{M})$, PPADS $(50 \mu \mathrm{M})$, RB-2 $(5 \mu \mathrm{M})$, and suramin $(100 \mu \mathrm{M})$; each was applied together with 2-MeSADP $(50 \mu \mathrm{M})$.

2-MeSADP increased significantly the accumulation of inositol phosphates in a dose-dependent manner (Fig. 1A). Under the same assay conditions, application of those agents up to $1 \mathrm{mM}$ showed no change in the intracellular cAMP level (Fig. 1B). Stimulation by forskolin served as a positive control and showed a $\sim 17$-fold increase in cAMP level; none of the nucleotide treatments used inhibited that forskolin response (Fig. 1B).

For comparison, COS-7 cells transiently expressing the recombinant $\mathrm{P} 2 \mathrm{Y}_{1}$ receptor were treated under the same conditions. The line of COS-7 cells used contains endogenous receptors that behave similarly to $\mathrm{P} 2 \mathrm{Y}_{2}$ receptors, and these untransfected cells responded to ATP and UTP but not to the $\mathrm{P}_{2} \mathrm{Y}_{1}$ agonists 2-MeSADP or 2-MeSATP (Fig. 2). In the COS-7 cells heterologously expressing the $\mathrm{P}_{2} \mathrm{Y}_{1}$ receptor, the intracellular level of inositol phosphates was increased by the application of 2-MeSATP, 2-MeSADP, or ATP, as in myotubes (Fig. 2). Under these conditions adenosine was inactive, showing that no fraction of the response to ATP in the myotubes (Fig. 2) is due its degradation to adenosine and subsequent activation of adenosine receptors. The $\mathrm{P}_{2} \mathrm{Y}_{1}$-specific antagonist A3P5P (Boyer et al., 1996), as well as the wide-range P2 antagonists PPADS, RB2, and suramin, were each able to block completely the accumulation of 2-MeSADP-induced inositol phosphates in the myotubes, as with the recombinant $\mathrm{P} 2 \mathrm{Y}_{1}$ receptor (Fig. 2). UTP, which has negligible activity at the chicken $\mathrm{P}_{2} \mathrm{Y}_{1}$ receptor, is active on the myotubes (Fig. 2). Overall, the patterns of second messenger respon-
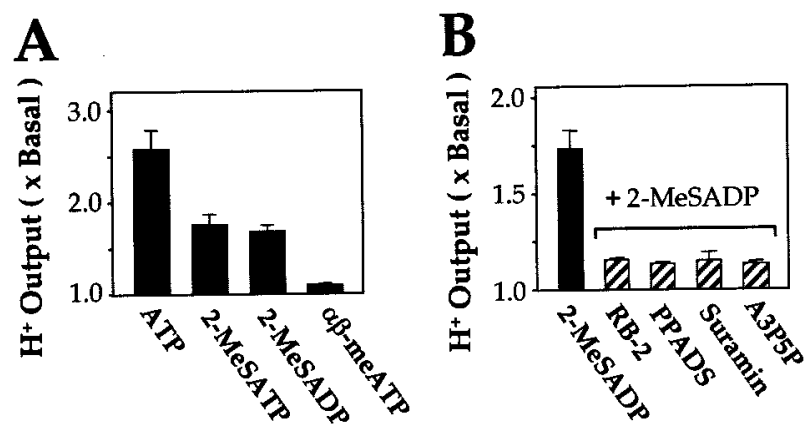

Figure 3. Extracellular output of $\mathrm{H}^{+}$ions from chick myotubes is activated by $\mathrm{P}_{2} \mathrm{Y}_{1}$ agonists and blocked by $\mathrm{P} 2 \mathrm{Y}$ antagonists. $A$, Myotubes, treated as for Figure 1, were exposed for 6 min to the agonists shown (50 $\mu \mathrm{M}$, superfused at $100 \mu \mathrm{l} / \mathrm{min}) . B$, Treatment with $50 \mu \mathrm{M} 2-\mathrm{MeSADP}$, alone or (right-hand set of bars) plus the antagonists shown (concentrations as in Fig. 2). The $\mathrm{H}^{+}$output from the cell to the medium, which induced a change of $\mathrm{pH}$, was determined by the sensor. Values are expressed as the ratio to the basal level (i.e., where no drug was present in the perfusing medium). Data are mean \pm SEM values for four independent experiments, each with triplicate samples.

siveness and of agonist and antagonist selectivity on the chick muscle cells could be accounted for by a predominant $\mathrm{P} 2 \mathrm{Y}_{1}$ receptor subtype together with a smaller contribution from one or more other receptors activated by UTP and ATP. This would also account for the biphasic form of the ATP concentration-response curve and for the greater response to ATP than to 2-MeSADP or 2-MeSATP (Fig. 1A).

The additional $\mathrm{P} 2 \mathrm{Y}$ receptor subtype(s) could not be identified at present, because only the $\mathrm{P} 2 \mathrm{Y}_{1}, \mathrm{P} 2 \mathrm{Y}_{3}$, and $\mathrm{P} 2 \mathrm{Y}_{5}$ receptors have been cloned from chicken. The chicken $\mathrm{P} 2 \mathrm{Y}_{3}$ receptor (which is highly sensitive to UDP) is not expressed in chick muscle (Webb et al., 1996), nor is the $\mathrm{P}_{2} \mathrm{Y}_{5}$ receptor [which has recently been shown to give functional responses to ATP in heterologous expression (King and TownsendNicholson, 2000)]. The total absence of the mRNA of either of these in the myotubes was confirmed by Northern blotting (data not shown). The $\mathrm{P}_{2} \mathrm{Y}_{4}$ receptor of the rat (Webb et al., 1998) and the $\mathrm{P} 2 \mathrm{Y}_{2}$ receptor as cloned from several mammals (Lustig et al., 1993; Parr et al., 1995) are activated by UTP and ATP and insensitive to 2-MeSATP or 2-MeSADP; the presence of a chick ortholog of either (or both) would account for the additional component seen here.

Functional analysis was also performed using microphysiometry, which sensitively detects a change of extracellular $\mathrm{pH}$ during agonist application. In chick myotubes, ATP, 2-MeSATP, and 2-MeSADP each induced a significant change in the $\mathrm{H}^{+}$output, but not $\alpha \beta$-meATP (Fig. 3). The 2-MeSADPinduced activation was blocked by the P2 antagonists RB-2, PPADS, and suramin and by the $\mathrm{P}_{2} \mathrm{Y}_{1}$-selective antagonist A3P5P (Fig. 3). These agonist and antagonist selectivities again reflect the pharmacological characteristics of a $\mathrm{P} 2 \mathrm{Y}_{1}$ receptor in chick myotubes.

\section{ATP-induced calcium mobilization}

Mobilization of $\mathrm{Ca}^{2+}$ from cytosolic stores during activation by ATP and ADP is a well established consequence of $\mathrm{P} 2 \mathrm{Y}_{1}$ receptor activation in other cell types. Chick myotubes in culture were preloaded with calcium green-1, and the mobilization of cytosolic $\mathrm{Ca}^{2+}$ during agonist stimulation was monitored by the induced fluorescence in real time in the fluorescence microscope. The cytosolic $\mathrm{Ca}^{2+}$ sharply increased across the myotube in $<30 \mathrm{sec}$ 
A
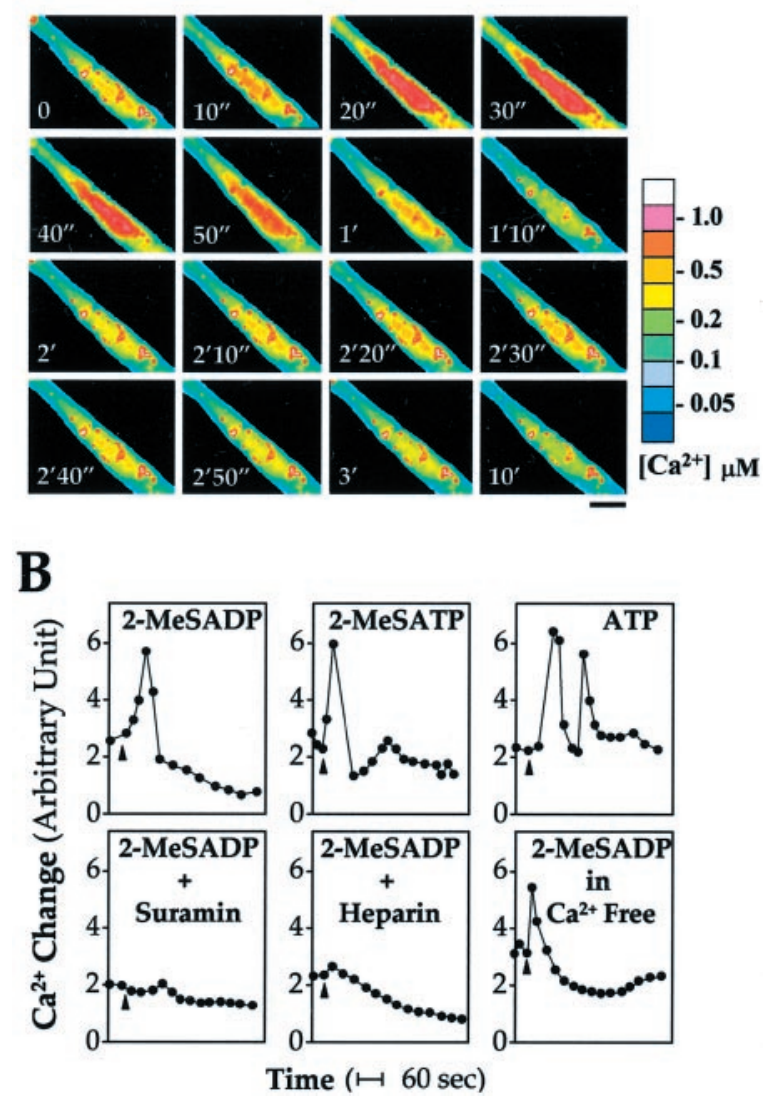

Figure 4. Intracellular $\mathrm{Ca}^{2+}$ mobilization in response to $\mathrm{P}_{2} \mathrm{Y}_{1}$ receptor agonists. $A$, Calcium green-1 fluorescence images of myotubes, captured at the times shown after 2-MeSADP $(100 \mu \mathrm{M})$ application at $37^{\circ} \mathrm{C}$. Calcium concentration (on the right) was calibrated from a standard curve. Scale bar, $20 \mu \mathrm{m}$. $B$, Responses obtained as shown in $A$ were digitally integrated to compare on a relative scale of their time courses. ATP $(100 \mu \mathrm{M})$ or 2-MeSADP or 2-MeSATP was applied at zero time (arrowhead). Co-applied suramin $(100 \mu \mathrm{M})$ completely blocks the induced mobilization, as does preloaded heparin $(5 \mathrm{mg} / \mathrm{ml})$. The response is not affected by removal of $\mathrm{Ca}^{2+}$ from the medium. One representative experiment is shown, the results being completely replicated in three independent experiments.

after the application of ATP (Fig. 4A). The time course of the $\mathrm{Ca}^{2+}$ signal is plotted in Figure $4 B$ for three $\mathrm{P}_{2} \mathrm{Y}_{1}$ receptor agonists. The calculated mean $\mathrm{Ca}^{2+}$ concentration changed from $\sim 0.09 \mu \mathrm{M}$ in the resting state to $\sim 0.5 \mu \mathrm{M}$ in the stimulated state. The general P2 antagonist, suramin, blocked the 2-MeSADPinduced cytosolic $\mathrm{Ca}^{2+}$ accumulation; it was also completely blocked by preloading the cells with heparin, an antagonist of inositol trisphosphate receptors (Wu et al., 2000). In addition, it was unchanged when the myotubes were cultured in $\mathrm{Ca}^{2+}$-free medium (Fig. 4B). Hence, the source of the induced accumulation was confirmed to be the intracellular stores.

It was found reproducibly that a doublet of $\mathrm{Ca}^{2+}$ waves was induced by ATP, in contrast to the single $\mathrm{Ca}^{2+}$ transient seen with 2-MeSADP and 2-MeSATP (Fig. 4B). Such multiple $\mathrm{Ca}^{2+}$ responses have been seen with ATP and UTP (but not with ADP) in rat hepatocytes, where both $\mathrm{P}_{2} \mathrm{Y}_{1}$ and $\mathrm{P}_{2} \mathrm{Y}_{2}$ receptors were shown to be expressed endogenously (Dixon et al., 2000).

\section{A Skeletal Muscle}

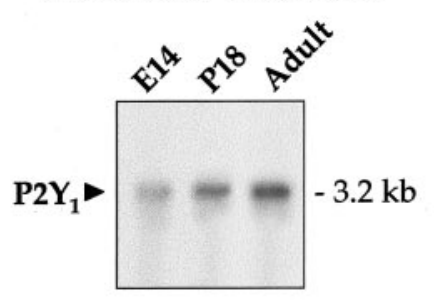

B

\section{Skeletal Muscle}
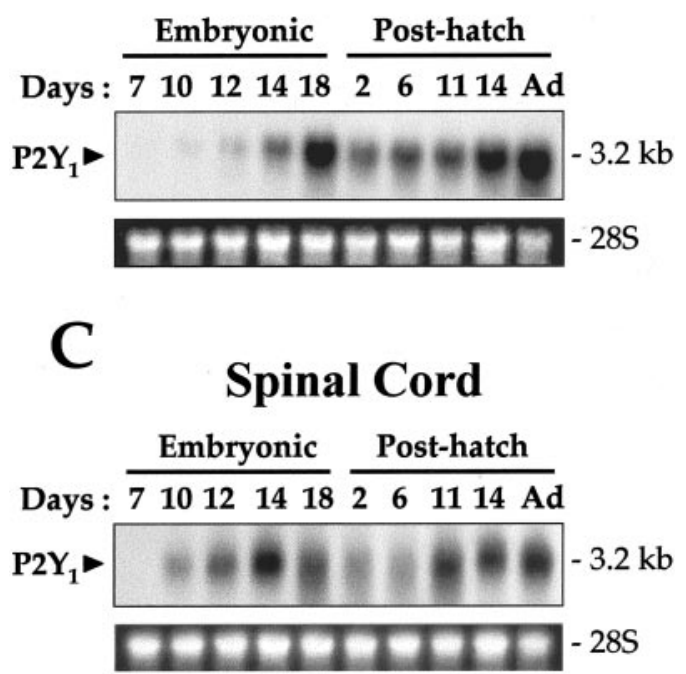

Figure 5. Changes in $\mathrm{P}_{2} \mathrm{Y}_{1}$ receptor mRNA levels in chick spinal cord and muscle during development. $A, \mathrm{~A}$ low exposure of the blot to show a single $\mathrm{P} 2 \mathrm{Y}_{1}$ receptor transcript at $\sim 3.2 \mathrm{~kb}$ is detectable in chicken muscle, from $14 \mathrm{~d}$ embryo (E14) or $18 \mathrm{~d}$ post-hatch (P18) or adult. Expression of the $\mathrm{P}_{2} \mathrm{Y}_{1}$ receptor transcript was examined in chick gastrocnemius muscle $(B)$ and spinal cord $(C)$ from embryonic day 7 to adult ( $A d ; 6$ months) as indicated. Ribosomal RNA loading markers $(28 S)$ are shown.

\section{Regulation of P2Y1 receptor mRNA synthesis in muscle and spinal cord}

A single transcript $(\sim 3.2 \mathrm{~kb})$ for the $\mathrm{P}_{2} \mathrm{Y}_{1}$ receptor was found in Northern blots of chick muscle and spinal cord RNA. This was true for embryonic day (E) 18 post-hatch and adult muscles (Fig. $5 A$ ), expanding the original finding of Webb et al. (1993). In E7 spinal cord, this $\mathrm{P}_{2} \mathrm{Y}_{1}$ mRNA was below the detectable level. The transcript level increased significantly from E10 until hatching. Post-hatch it was initially lower (per micrograms of total RNA present) but increased considerably up to approximately day 11 and remained equally high in the adult (Fig. 5C). Chick skeletal muscle showed a roughly similar profile to the spinal cord, but expression there was reproducibly highest in the adult (Fig. $5 B$ ). When normalized for the amount of RNA loaded onto the gel, there was (at all stages) approximately threefold higher expression of $\mathrm{P}_{2} \mathrm{Y}_{1}$ receptor mRNA in muscle than in the spinal cord.

The level of $\mathrm{P}_{2} \mathrm{Y}_{1}$ receptor transcript was examined after denervation and subsequent nerve regeneration. In denervated gastrocnemius muscle of the 18-d-old chick, the level of P2Y receptor transcript was decreased $\sim 10$-fold at day 2 after denervation (Fig. 6). This expression remained very low until $\sim 30 \mathrm{~d}$ after denervation, when reinnervation begins (Ip et al., 1996) in the system used. This restored the $\mathrm{P}_{2} \mathrm{Y}_{1}$ receptor mRNA expres- 


\section{Chick}

\section{Rat}

Denervation

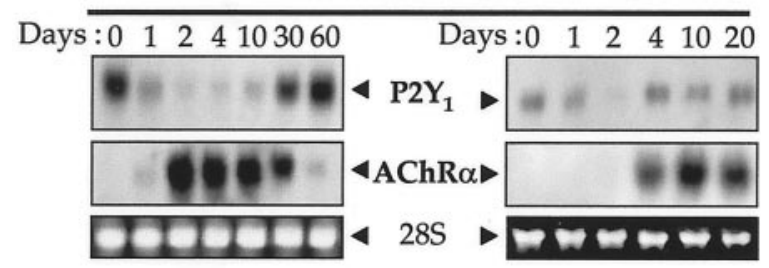

Nerve Crush

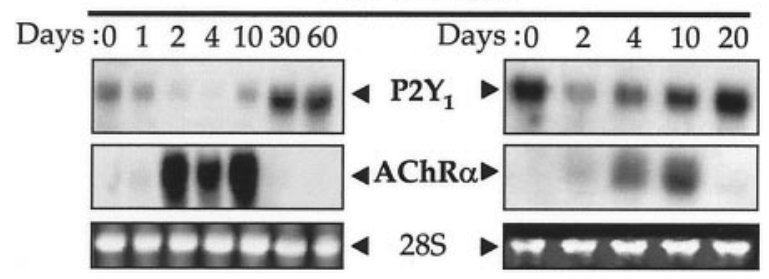

Figure 6. The transcript encoding the $\mathrm{P}_{2} \mathrm{Y}_{1}$ receptor is downregulated in muscles after reversible nerve denervation or nerve crush. Gastrocnemius muscles of P18 chicks (left panels) or of adult rats (right panels) were treated as indicated. $\mathrm{P} 2 \mathrm{Y}_{1}$ receptor mRNA (at $\sim 3.2 \mathrm{~kb}$ for chick and $\sim 3.6$ $\mathrm{kb}$ for rat) is shown in Northern blots at the indicated days after operation. The AChR $\alpha$-subunit (at $\sim 3.2 \mathrm{~kb}$ ) in both chick and rat muscles served as an internal marker for effective nerve denervation or crush: that mRNA is greatly upregulated after denervation or nerve crush but declines to the original low level as reinnervation proceeds after the longer periods.

sion thereafter (Fig. 6). To assess the effectiveness of the denervation procedure, the levels of AChR $\alpha$-subunit transcript at $\sim 3.2$ $\mathrm{kb}$ were also determined, and as is general in vertebrate skeletal muscles during denervation, this AChR subunit was greatly increased, here by $>20$-fold after $2 \mathrm{~d}$ (Fig. 6). This effect and the decline seen at $\sim 30 \mathrm{~d}$ after denervation for AChR $\alpha$-subunit mRNA expression were similar to the previously reported findings for this muscle system (Ip et al., 1996). The same procedures were applied to the adult rat gastrocnemius muscle, with similar results (Fig. 6). In the rat a transcript was revealed at $\sim 3.6 \mathrm{~kb}$, corresponding to the known rat $\mathrm{P}_{2} \mathrm{Y}_{1}$ receptor mRNA. The return of the $\mathrm{P}_{2} \mathrm{Y}_{1}$ receptor mRNA in the reinnervation phase began in the rat muscle before the AChR mRNA declined again. An alternative temporary interruption of the motor nerve influence, reversible nerve crush, was also used, in both the chick and the adult rat. The expression of the $\mathrm{P}_{2} \mathrm{Y}_{1}$ mRNA was decreased by the nerve crush (when assessed by densitometry) to a similar extent as before, by $80-90 \%$ in both species. The P2 $\mathrm{Y}_{1}$ mRNA returned to the normal level in the regeneration phase, and this again occurred faster in the adult rat (Fig. 6). The effectiveness of neural interruption, and of the neural regeneration, was likewise confirmed in each crush case by the upregulation and later downregulation of the AChR $\alpha$-subunit (Fig. 6).

\section{Localization of $\mathrm{P}_{2} \mathrm{Y}_{1}$ receptor protein at the neuromuscular junction}

The localization of $\mathrm{P}_{2} \mathrm{Y}_{1}$ receptor protein in skeletal muscle was determined using a polyclonal antibody directed against the $\mathrm{C}$-terminal portion of the chicken $\mathrm{P}_{2} \mathrm{Y}_{1}$ receptor. The antibody recognized a protein band with an apparent molecular mass of $\sim 50 \mathrm{kDa}$ from cell membranes heterologously expressing the chicken $\mathrm{P}_{2} \mathrm{Y}_{1}$ receptor (data not shown). The full characteriza-
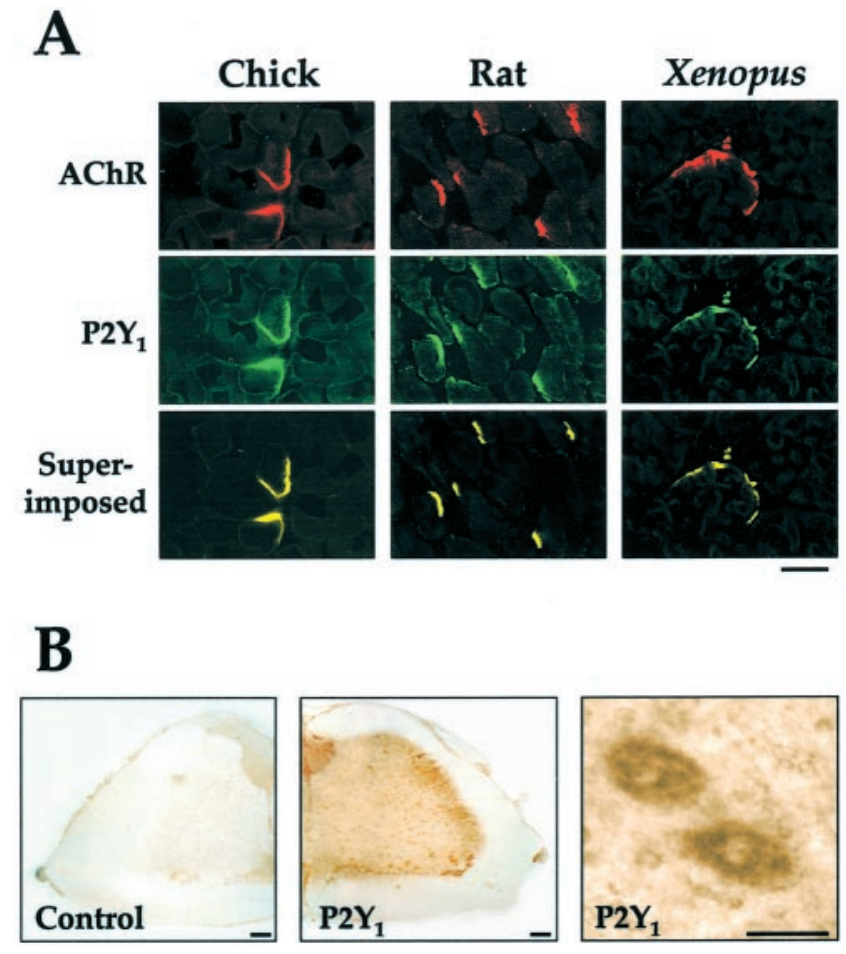

Figure 7. The localizations of $\mathrm{P}_{2} \mathrm{Y}_{1}$ receptor in muscles and motor neurons. $A$, Chick, rat, or Xenopus muscle section $(20 \mu \mathrm{m})$ was used. For each, the same field is shown stained by the anti-P2 $\mathrm{Y}_{1}$-receptor antibody (green) or for AChR (red) by TMR-BuTX (10 nM) or superimposed (yellow). Controls are noted in Results. Scale bar, $20 \mu \mathrm{m}$. B, Spinal cord from adult chicken. Peroxidase-conjugated secondary antibody was used here to reveal (brown) the $\mathrm{P}_{2} \mathrm{Y}_{1}$ receptor sites in the ventral horn. In the control, the antibody was pretreated with an excess of the recombinant $\mathrm{P} 2 \mathrm{Y}_{1}$ receptor antigen. A high-power magnification is shown for two adjacent positive cells seen in the stained low-power field. Scale bars, 500 $\mu \mathrm{m}$ (low power); $100 \mu \mathrm{m}$ (high power).

tion of this antibody will be published elsewhere. For control, the immunofluorescence observed with this antibody on each type of muscle section studied was completely blocked by the chicken $\mathrm{P}^{2} \mathrm{Y}_{1} \mathrm{C}$-terminal peptide that had been used as the immunogen (data not shown). The $\mathrm{P}_{2} \mathrm{Y}_{1}$ immunoreactivity was colocalized with the binding of tetramethyl-rhodamine-conjugated $\alpha$-bungarotoxin, indicating the restricted localization of $\mathrm{P}_{2} \mathrm{Y}_{1}$ receptor at the adult neuromuscular junctions (Fig. 7A). That location of $\mathrm{P}_{2} \mathrm{Y}_{1}$ receptor was revealed not only in chicken muscle, but it was also colocalized with AChR in adult rat and Xenopus muscles (Fig. 7A). Cross-reactivity was expected because the chicken sequence used as immunogen has $86 \%$ identity to that region in the rat $\mathrm{P} 2 \mathrm{Y}_{1}$ receptor.

The extent of colocalization was also analyzed during the development of chick muscles. From E10 to E19, there was no significant colocalization of $\mathrm{P}_{2} \mathrm{Y}_{1}$ receptors with the AChRs. However, a high degree of colocalization of $\mathrm{P}_{2} \mathrm{Y}_{1}$ receptors with AChRs in chick muscles was revealed during later stages of development, from P20 to adulthood (Fig. 8). A very weak staining by anti-P2 $\mathrm{Y}_{1}$ receptor antibody could still be observed in some extra-junctional areas.

Because an appreciable concentration of the $\mathrm{P}_{2} \mathrm{Y}_{1}$ receptor mRNA was found in the developing and adult spinal cord (Fig. $5 B$ ), the question arose as to whether it is located in the motor neurons there. If so, does it produce the protein for axonal transport to their terminals in the muscles, as a presynaptic 


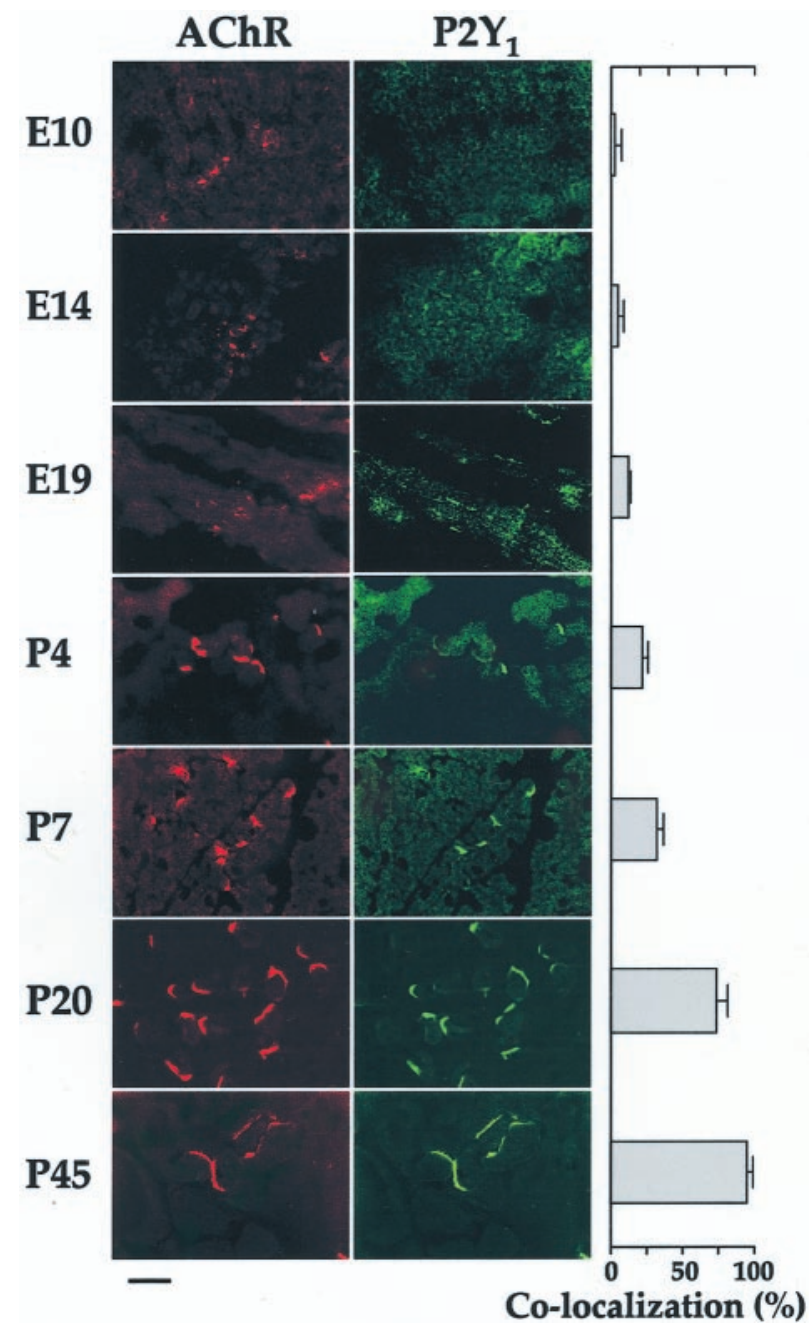

Figure 8. Colocalization of $\mathrm{P}_{2} \mathrm{Y}_{1}$ receptors and AChRs in chick muscle during development. Sections are double stained as in Figure 7. Chick pectoral muscle was used from embryonic day $10(E 10)$ to post-hatch day 45 (P45). The percentage of colocalization between $\mathrm{P}_{2} \mathrm{Y}_{1}$ receptors and AChRs was determined manually (see Materials and Methods) after revealing AChR staining first, and then shifting the red fluorescence filter to green for the detection of $\mathrm{P}_{2} \mathrm{Y}_{1}$ receptor staining. Data are mean \pm SEM values, from counts over five or six fields from each of 10 sections from four animals. Scale bar, $10 \mu \mathrm{m}$.

receptor, which might contribute to the junctional concentration seen in Figures 7 and 8 . When sections of chick spinal cord were stained with the anti-P2 $\mathrm{Y}_{1}$ antibody, motor neurons (having large nuclei and cell bodies) at the ventral horn of the cord were identified and seen to be strongly stained (Fig. 7B). Hence, at least a significant fraction of the $\mathrm{P} 2 \mathrm{Y}_{1}$ receptor translated in the motor neurons is present in the cell bodies, being partly in the region of the somatic cell membranes and partly cytoplasmic. This therefore leaves open the possibility that some is transported to become a presynaptic receptor at the terminals in the muscles. Testing this would require higher resolution, in a future electron microscope immunolocalization study when an antibody resistant to the procedures involved is obtained.

\section{Activation or overexpression of $\mathrm{P}^{2} \mathrm{Y}_{1}$ receptors induces AChR and AChE expression}

A potential regulatory function of $\mathrm{P} 2 \mathrm{Y}_{1}$ receptors, to induce the expression of $\mathrm{AChE}$ and $\mathrm{AChR}$, was explored in cultured myo- tubes. After the addition to the culture medium of 2-MeSADP $(50 \mu \mathrm{M})$, the expression of transcripts encoding the AChR $\alpha$-subunit rose to a maximum of 5.7-fold the level in the ligandfree control culture; for the mRNA of the AChE catalytic subunit ( $\sim 4.8$ and $\sim 6.0 \mathrm{~kb}$ isoforms), a similar stimulation occurred (Fig. $9 A)$. A lag phase of $\sim 8 \mathrm{hr}$ was seen with both, and a plateau was reached by $48 \mathrm{hr}$. The lag is consistent with activation of mRNA syntheses. The results were the same with $100 \mu \mathrm{M} 2-\mathrm{MeSADP}$ and similar at $10 \mu \mathrm{M}$ except that the level of stimulation was then lower (data not shown). ATP, ADP, and 2-MeSATP, applied for $24 \mathrm{hr}$, all gave statistically significant elevations of these mRNAs (Fig. 9B). The time course with 2-MeSATP was also tested and found to give results for each mRNA that were indistinguishable from those in Figure $9 A$ (data not shown). Protection of the nucleotides from metabolism (see Materials and Methods) was applied throughout this period. The AChE protein levels were also determined during these incubations, using an AChE-specific antibody (Tsim et al., 1988). The content of the AChE catalytic subunit (apparent molecular mass $\sim 105 \mathrm{kDa}$ ) was increased up to 1.6-fold the control level by the application of ATP or 2-MeSATP, but not at all by adenosine (Fig. 9C). The level of the control protein $\alpha$-tubulin $(\sim 55 \mathrm{kDa})$ was not affected by the ligands (Fig. 9C). Suramin $(100 \mu \mathrm{M})$ was able to block completely this ATP-induced AChE protein synthesis. Myotubes secrete some of their AChE into the medium (Rotundo, 1988; Choi et al., 1998), but all of the ATP-mediated increase in AChE protein here was within the cells, the level in the medium being unaltered (data not shown).

A more dramatic induction of $\mathrm{AChE}$ protein synthesis was found when the recombinant chicken $\mathrm{P}_{2} \mathrm{Y}_{1}$ receptor was overexpressed in the myotubes and again activated as before by $50 \mu \mathrm{M}$ 2-MeSATP; the increase in the $\mathrm{P}_{2} \mathrm{Y}_{1}$ receptor content stimulated the production of $\mathrm{AChE}$ protein to severalfold the control level of cells transfected with the empty vector or the level in untransfected cells stimulated likewise by the agonist (Fig. 9C). However, although the AChE protein level was increased by ATP treatment and further by $\mathrm{P} 2 \mathrm{Y}_{1}$ receptor overexpression, the AChE enzymatic activity remained unchanged (Fig. 9C). This behavior is parallel to that which we have found for AChE (Choi et al., 1996, 1998) in muscle cells exposed to CGRP, another regulatory factor released from the motor nerve terminals. CGRP was known previously to increase the expression of AChR subunits in cultured muscle cells (New and Mudge, 1986; Fontaine et al., 1987; Moss et al., 1991). When myotubes are stimulated by CGRP, AChE mRNA and protein increase as here, but the enzymatic activity does not (Choi et al., 1998).

To confirm that these stimulations arise directly from ATPinduced gene activation, the promoters of the human $\mathrm{AChE}$ catalytic subunit and the chicken AChR $\alpha$-subunit in a vector were tagged downstream with the luciferase reporter gene, giving the pAChE-Luc and pAChR $\alpha$-Luc constructs. When transfected into myotubes, the selective agonist 2-MeSATP induced the promoter activities in a dose-dependent manner (Fig. 10A). The extent and concentration-dependence of the 2-MeSATP activation were identical for the AChE and the AChR gene promoters (Fig. 10A). The conclusion that this intracellular effect on the two specific gene promoters is mediated through the $\mathrm{P} 2 \mathrm{Y}_{1}$ receptor on the cell membrane was further tested by using the aforementioned $\mathrm{P}_{2} \mathrm{Y}_{1}$ receptor-specific antagonist, A3P5P. A3P5P (50 $\left.\mu \mathrm{M}\right)$ gave a significant block of the action of either ATP or 2-MeSATP. The general P2 antagonist, suramin $(50 \mu \mathrm{M})$, was also effective in blockade (Fig. 10B). Furthermore, when either pAChE-Luc or 
Figure 9. $\quad \mathrm{P}_{2} \mathrm{Y}_{1}$ receptor agonists stimulate the expression of AChE catalytic subunit and AChR $\alpha$-subunit. Agonists alone or together with antagonists were applied onto cultured myotubes (with 3 changes of medium and the appropriate ligand-regenerating enzyme system present, during the incubation at $\left.37^{\circ} \mathrm{C}\right) . A$, The induction of transcripts encoding $\mathrm{AChE}(\sim 4.8$ and $\sim 6.0 \mathrm{~kb})$ and $\mathrm{AChR} \alpha$-subunit $(\sim 3.2 \mathrm{~kb})$ by $50 \mu \mathrm{M} 2-\mathrm{MeSADP}$ is shown as a function of time, and the quantitation from such blots is shown by densitometry. Total RNA applied per lane was $30 \mu \mathrm{g}$. Values are expressed as the percentage of the increase in each mRNA, above the control level, which is measured in samples from myotubes incubated in parallel without ligand and run in an adjacent lane. $B$, Transcripts of $\mathrm{AChE}$ and $\mathrm{AChR}$ $\alpha$-subunit are increased by ATP, ADP, 2-MeSADP, and 2-MeSATP applications (each $50 \mu \mathrm{M}, 24 \mathrm{hr}$ treatment). Total RNA applied per lane was $30 \mu \mathrm{g}$. The bottom panel in $B$ shows the quantitation from such blots by densitometry. Values are expressed as in $A$. $C$, After drug treatments of myotubes as above, or after ATP plus suramin $(100 \mu \mathrm{M})$, total protein was extracted into SDS medium at $100^{\circ} \mathrm{C}$ and loaded ( $20 \mu \mathrm{g}$ per lane) for Western blotting of AChE catalytic subunit ( $\sim 105 \mathrm{kDa}$ ) as shown in the top panel (only representative lanes are shown there for clarity). This procedure was also applied (last lane) to myotubes that were supertransfected with cDNA encoding the chicken $\mathrm{P}_{2} \mathrm{Y}_{1}$ receptor $(1 \mu \mathrm{g}$ total DNA per well) and exposed to $50 \mu \mathrm{M}$ 2-MeSATP as above. The stimulation by ATP or 2-MeSATP of AChE protein formation in these cells was quantitated on the blots by densitometry. Samples of the same ligand-treated cell cultures were extracted and assayed for AChE enzyme activity. Values are expressed as in $A$, for either the AChE enzymatic activity or the AChE protein content. As a marker of sample protein, $\alpha$-tubulin protein $(\sim 55 \mathrm{kDa})$ was detected by its antibody in the same gel lane in each case and quantitated similarly. Its amount was approximately the same in all samples, and it was unaffected by the ligands (data not shown). The same analyses were also performed on the myotubes that were supertransfected with a vector encoding the $\mathrm{P}_{2} \mathrm{Y}_{1}$ receptor cDNA (last set), with the control level being that in cells transfected with the vector alone and without ligand added. Changes from the control level are significant at $p<0.01$ (asterisk) by $t$ test. All data are mean \pm SEM values from four independent experiments.

pAChR $\alpha$-Luc was cotransfected as above with cDNA encoding the chicken $\mathrm{P}_{2} \mathrm{Y}_{1}$ receptor and stimulated (with either 2-MeSATP or 2-MeSADP), a dramatic increase in luciferase activity was produced. This increase in luciferase activity was doubled (to reach approximately eightfold the basal level, for pAChE-Luc) when the $\mathrm{P} 2 \mathrm{Y}_{1}$-plasmid concentration was increased from 1 to $2 \mu \mathrm{g}$ per well (Fig. 10C). In this case, the effect on the AChE gene promoter was greater. Again, both AChE and AChR $\alpha$-subunit gene activation induced by $\mathrm{P}_{2} \mathrm{Y}_{1}$ receptor overexpression were blocked by suramin in a dose-dependent manner (Fig. 10C).

\section{DISCUSSION}

\section{The $\mathrm{P}_{2} \mathrm{Y}_{1}$ receptor in skeletal muscle}

$\mathrm{P} 2 \mathrm{Y}_{1}$ is clearly an abundant receptor of skeletal muscle. The $\mathrm{P}_{2} \mathrm{Y}_{1}$ receptor mRNA was already known to be strongly ex-
A

Time (hr) $\overline{02482448}$

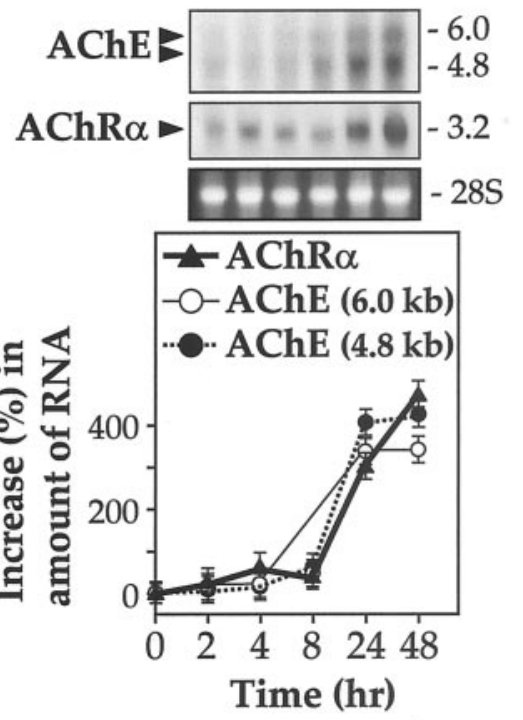

B
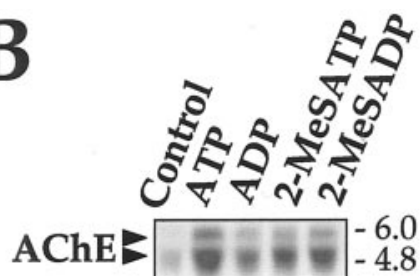

$\mathrm{AChR} \alpha-\mathrm{-e}=-3.2$ cese-285

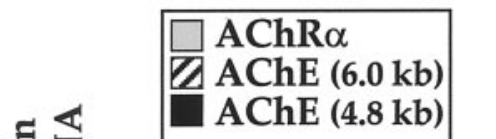

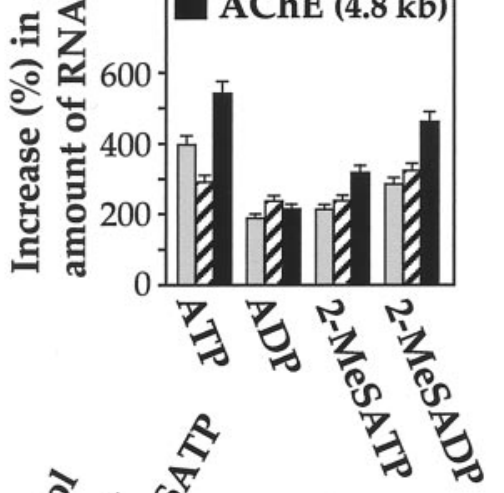
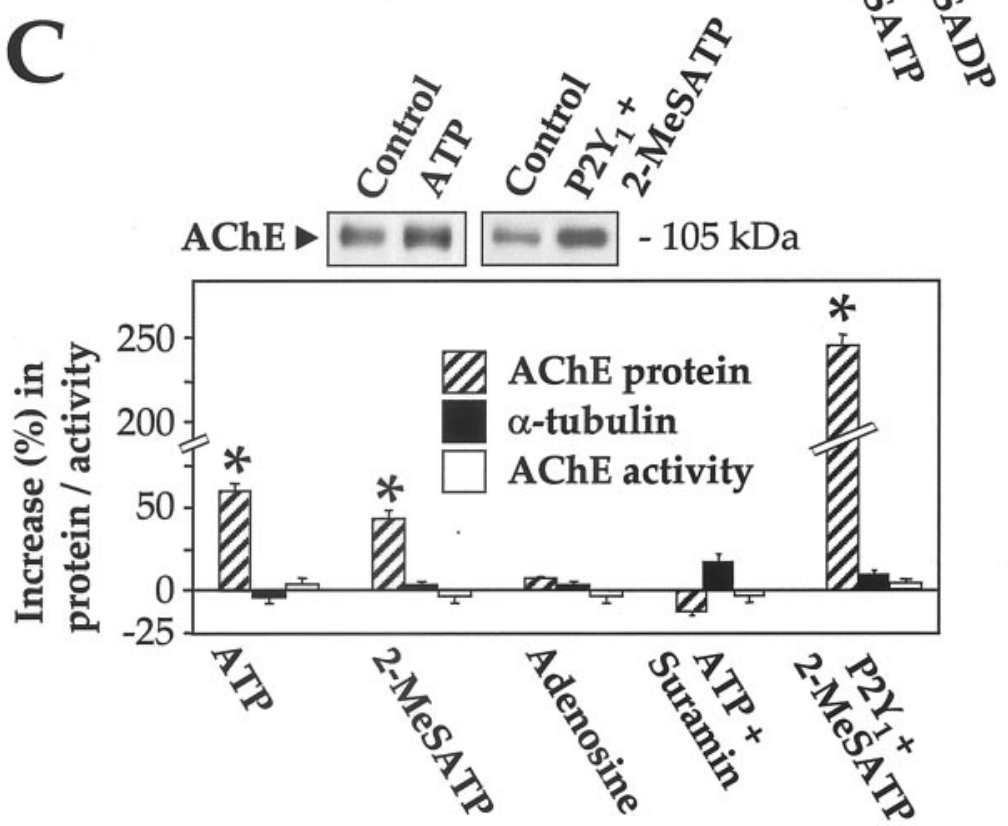

pressed in chicken (Webb et al., 1993) and human (Ayyanathan et al., 1996) adult skeletal muscles; this mRNA was also noted (Meyer et al., 1999a) in chick embryo limb buds. Here we demonstrate the mRNA (Fig. 5) and protein (Figs. 7, 8) of the P2Y receptor in adult rat and amphibian muscles, and in chicken muscle cells at all stages from E10 to the adult. A functionally significant finding is that in developed muscle these $\mathrm{P} 2 \mathrm{Y}_{1}$ receptors are localized to the neuromuscular junctions (Figs. 7, 8). This could provide a molecular basis for the postsynaptic potentiating effects of the ATP that is co-released with acetylcholine (see introductory remarks), effects that in avian and mammalian developed muscle show characteristics of a second messenger system (Henning, 1997). We could not distinguish in the light microscope between postsynaptic and presynaptic sites for the $\mathrm{P} 2 \mathrm{Y}_{1}$ receptors, but we deduce that at least many of these are postsynaptic, because (1) here these receptors were also found in active 

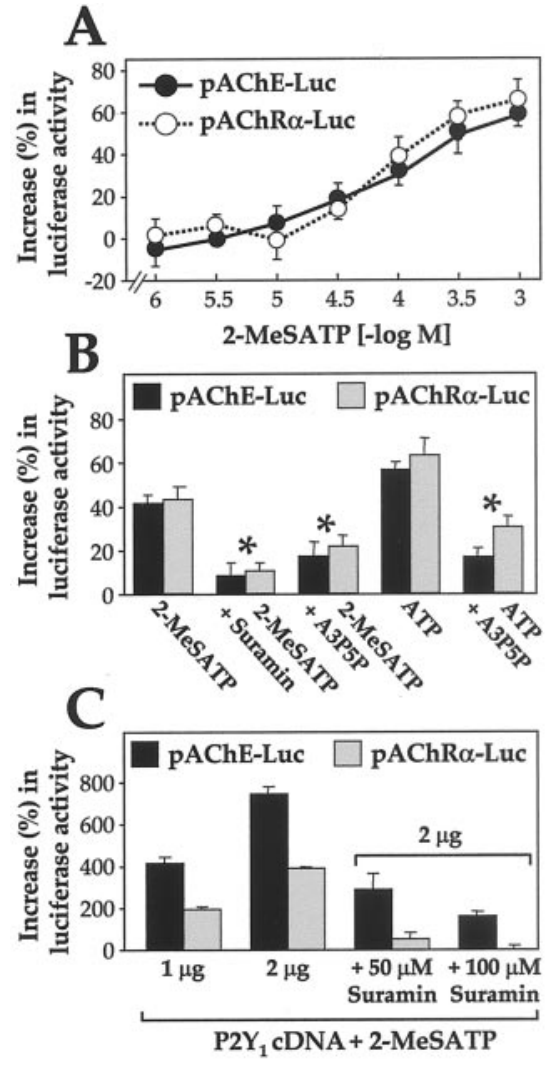

Figure 10. Promoters of the AChE catalytic subunit and AChR $\alpha$-subunit genes are activated by ATP and 2-MeSATP. A, Two days after transfection of myotubes (in 12-well plates) with pAChE-Luc or pAChR $\alpha$-Luc, 2-MeSATP concentrations were applied onto the myotubes for $24 \mathrm{hr}$ in the protective conditions used for Figure 9. The luciferase activity was finally assayed in a lysate of the cells. Values are expressed as the percentage of the increase in activity, above the control level measured in samples from transfected myotubes incubated in parallel without ligand. $B$, Chick myotubes transfected with pAChE-Luc or $\operatorname{pAChR} \alpha$-Luc were treated with a $\mathrm{P}_{2} \mathrm{Y}_{1}$ receptor agonist $(100 \mu \mathrm{M})$ and analyzed, and the results are expressed as in $A$. The agonist was present alone or with an antagonist, A3P5P $(50 \mu \mathrm{M})$ or suramin $(50 \mu \mathrm{M})$. UDP or UTP $(50 \mu \mathrm{M})$ had no effect (data not shown). The antagonists reduced significantly ( $p<0.01$ by $t$ test; asterisk) the effect of agonists. $C$, A vector encoding the $\mathrm{P}_{2} \mathrm{Y}_{1}$ receptor cDNA was cotransfected $(1$ or $2 \mu \mathrm{g}$ DNA per well) with pAChE-Luc or pAChR $\alpha$-Luc and after $2 \mathrm{~d}$ incubation and a wash was incubated as above with 2 -MeSATP $(50 \mu \mathrm{M})$. The activity is expressed relative to the control level of cells in which the $\mathrm{P}_{2} \mathrm{Y}_{1}$-cDNA vector was replaced by the vector alone. Induction of each gene expression is seen, which is approximately doubled when the cDNA concentration applied is doubled (first 2 sets). 2-MeSADP (50 $\mu \mathrm{M})$ incubation of these $\mathrm{P} \mathrm{Y}_{1}$-transfected cells gave essentially the same values as with 2-MeSATP (data not shown). In the blocking experiment also shown (last 3 sets), $2 \mu \mathrm{g}$ $\mathrm{P}_{2} \mathrm{Y}_{1}$-vector per well DNA was transfected, and the incubation with 2-MeSATP $(50 \mu \mathrm{M})$ was made without (control) or with suramin (50 or $100 \mu \mathrm{M})$. All the data are mean \pm SEM values for four independent experiments.

form on myotubes in the absence of neurons; (2) although at neuromuscular junctions a presynaptic effect of ATP on acetylcholine release is known, this can be primarily accounted for by its hydrolysis by nucleotidases to adenosine, that effect being abolished by A1 receptor antagonists and mimicked by adenosine (Redman and Silinsky, 1994; Fu et al., 1997; Henning, 1997).

\section{$A$ role in the expression and maintenance of junctional} AChR and AChE

Our results suggest that an important function of extracellular ATP and its $\mathrm{P}_{2} \mathrm{Y}_{1}$ receptor on skeletal muscle is to participate in the control of postsynaptic gene expression of AChE and AChR. Thus, application of $\mathrm{P} 2 \mathrm{Y}_{1}$-selective agonists such as 2-MeSADP on myotubes induced the expression of the AChE catalytic subunit and of the AChR $\alpha$-subunit. This was in parallel with the $\mathrm{P}_{2} \mathrm{Y}_{1}$ receptor-mediated stimulation of inositol phosphate formation and of $\mathrm{Ca}^{2+}$ mobilization from intracellular stores, as well as a newly detected P2Y effect, the output of $\mathrm{H}^{+}$ions (Fig. 3). All of those responses were blocked by a $\mathrm{P} 2 \mathrm{Y}_{1}$-specific antagonist. Second, introduction of an excess of the $\mathrm{P} 2 \mathrm{Y}_{1}$ receptor greatly increased the expression of AChE protein. Third, the promoters of both the $\mathrm{AChE}$ and the $\mathrm{AChR} \alpha$ genes exhibit positive control by $\mathrm{P} 2 \mathrm{Y}_{1}$ receptor activation in a dose-dependent manner. Fourth, that latter effect was magnified, dose dependently, by overexpression of the recombinant chicken $\mathrm{P} 2 \mathrm{Y}_{1}$ receptor.

$\mathrm{P}_{2} \mathrm{Y}_{1}$ receptor expression rises strongly at the late embryonic period of neuromuscular junction formation and is highest in adult muscle, and the protein is concentrated at those junctions in adult life (Figs. 5, 7, 8). The neural release of ATP onto a muscle cell at the synapse is likewise continuous throughout postembryonic life. Similarly, the synthesis in muscles of the junctional AChR and AChE remains high in the adult (Duclert and Changeux, 1995; Krejci et al., 1999). The evidence just summarized on the expression of $\mathrm{AChE}$ and $\mathrm{AChR}$ suggests, therefore, a trophic function of the extracellular $\mathrm{ATP} / \mathrm{P} 2 \mathrm{Y}_{1}$ receptor system in the maintenance of those two components of the junction. Such an action would have to be integrated with concurrent regulation by other nerve-derived agents, e.g., CGRP and neuregulin (see introductory remarks). The expression in the multinucleated mature muscle fibers of synaptic AChR and of the heteromeric synaptic form ("A 12 ") of AChE is compartmentalized to the subsynaptic nuclei (Sanes et al., 1991; Tsim et al., 1992; Jasmin et al., 1993; Duclert and Changeux, 1995; Krejci et al., 1999), implying that intracellular signals from the membrane to those nuclei (Schaeffer et al., 1998) mediate the maintenance of those synaptic forms. Furthermore, specific isoforms of PKC [a kinase family established to be activable in cells by the $\mathrm{P} 2 \mathrm{Y}_{1}$ receptor (Sellers et al., 2001)] are also localized under the neuromuscular junctions (Hilgenberg et al., 1996). In support of such a maintenance role of the muscle $\mathrm{P}_{2} \mathrm{Y}_{1}$ receptor, we can refer to the significant observation of O'Malley et al. (1997) that continuous application of ATP stabilizes the rapidly degraded newly synthesized fraction of AChRs in rat myotubes.

\section{Activities of nucleotides on the muscle cells attributable to the $\mathrm{P}_{2} \mathrm{Y}_{1}$ receptor}

Certain other P2Y subtypes acting likewise might also be present in the innervated muscle, as is known by PCR detection in adult mammalian muscle (Webb et al., 1998) but unexplored in the chicken because of limited sequence information there. However, the $\mathrm{P}_{2} \mathrm{Y}_{1}$ selectivity, discussed above, of agonists and an antagonist, A3P5P, which are effective in all of the gene activation effects, plus the lack of gene effects with UTP or UDP, minimized any contribution from other subtypes, whereas the anti-P2 $\mathrm{Y}_{1}$ antibody and the effects of $\mathrm{P} 2 \mathrm{Y}_{1}$ overexpression provided positive identification.

Nevertheless, some features of the inositol phosphate and $\mathrm{H}^{+}$ ion responses (Figs. 2, 3) showed that P2Y receptor(s) other than $\mathrm{P}_{2} \mathrm{Y}_{1}$ is indeed present on the myotubes. The response in this case to UTP, together with the higher activity of ATP relative to 2-MeSATP and 2-MeSADP, can be explained by a lesser contribution from a $\mathrm{P} 2 \mathrm{Y}_{2}$ and/or $\mathrm{P}_{2} \mathrm{Y}_{4}$ receptor, as noted in Results. The above-mentioned ligand specificity criteria also mean that 
there is little or no contribution here from the P2X ion channel ATP receptors, which have been detected (see introductory remarks) on chick myotubes. Furthermore, channel responsiveness to ATP disappears in chick embryonic muscles by E17 (Wells et al., 1995), and in parallel the P2X receptors, earlier prominent (by antibody staining), decline (Meyer et al., 1999b; Bo et al., 2000). In rat embryonic muscles, likewise, the $\mathrm{P} 2 \mathrm{X}$ receptors are embryonic and all are lost by P14 (Ryten et al., 2001). This is the converse of the chick muscle $\mathrm{P}_{2} \mathrm{Y}_{1}$ receptor expression (Fig. 5). The muscle $\mathrm{P}_{2} \mathrm{Y}_{1}$ receptor develops later (Fig. 5) and, alone of the nucleotide receptors known in avian and mammalian skeletal muscles, will be available to transduce long-term trophic maintenance functions of ATP.

\section{Denervation effects and relation to AChE and AChR expression}

The rapid loss found after denervation or nerve crush, in both chicken and rat muscle, of the $\mathrm{P} 2 \mathrm{Y}_{1}$ receptor transcript is a parallel to the loss of the specific synaptic (collagen-tailed) AChE isoform in chicken (Silman et al., 1979) or mammalian muscle (Weinberg and Hall, 1979; Lai et al., 1986) and its mRNAs (Michel et al., 1994), which occurs after mature muscles are denervated. Both $\mathrm{P} 2 \mathrm{Y}_{1}$ receptor and synaptic AChE also are restored after reinnervation. The $\mathrm{P} 2 \mathrm{Y}_{1}$ disappearance could be attributable to loss of a trophic action of ATP, or to loss of another nerve-derived regulator such as CGRP if that can act on $\mathrm{P}_{2} \mathrm{Y}_{1}$ receptor synthesis as it does (Choi et al., 1998) (and see above) on the synaptic isoform of AChE. ATP and CGRP are thus seen to have a trophic effect in common: CGRP induces (in cultured myotubes) the upregulation of AChE protein but in an inactive form (Choi et al., 1998), as ATP did (Fig. 9) here. Pools of inactive and active AChE are known to occur in native muscles (Chatel et al., 1994). The reason is unclear, but this is not unique, and a reserve of incompletely folded protein has been suggested, because heat shock (which can release chaperone activity) recovered some AChE activity in chick myotubes (Eichler and Silman, 1995). However, the high proportion of AChE in the inactive pool, produced in myotubes during stimulation by ATP as here or by CGRP (Choi et al., 1998), may be caused by the lack of motor innervation, because $\sim 80 \%$ of AChE protein made normally in chick myotubes does not mature to the active form (Rotundo, 1988). Factor(s) for AChE maturation may be more available in mature innervated muscle.

Although denervation obviously removes the synaptic ATP influence, the muscle $\mathrm{AChR} \alpha$ expression, in an apparent paradox here, is increased greatly. This is, however, a long-known consequence in vertebrates, which is attributable to an independent and much stronger opposing effect of denervation, i.e., the liberation from the action potential-mediated suppression of AChR synthesis in all the extrasynaptic myonuclei (Duclert and Changeux, 1995). This is an overwhelming effect: the content of AChR mRNAs in the muscle can increase up to 100 -fold after denervation (Moscoso et al., 1995). For synaptic AChE and for P2Y receptors, there is no such de-repression of extra-junctional synthesis, so the loss of neural influence becomes evident. A working hypothesis, to be tested, is that ATP is in the same category as neuregulin (Moscoso et al., 1995; Sandrock et al., 1997; Schaeffer et al., 1998) and CGRP (Duclert and Changeux, 1995), which act via their postsynaptic receptors to activate factors locally to enhance transcription of AChR genes specifically in the adjacent subsynaptic nuclei.

\section{REFERENCES}

Akasu T, Hirai K, Koketsu K (1981) Increase of acetylcholine receptor sensitivity by adenosine triphosphate: a novel action of ATP on AChsensitivity. Br J Pharmacol 74:505-507.

Ayyanathan K, Webb TE, Sandhu AK, Athwal RS, Barnard EA, Kunapuli SP (1996) Cloning and chromosomal localization of the human $\mathrm{P} 2 \mathrm{Y}_{1}$ purinoceptor. Biochem Biophys Res Commun 218:783-788.

Barnard EA, Simon J (2001) An elusive receptor finally caught: P2 $Y_{12}$, an important drug target in platelets. Trends Pharmacol Sci 22:388-391.

Ben Aziz-Aloya R, Seidman S, Timberg R, Sternfeld M, Zakut H, Sorec $\mathrm{H}$ (1993) Expression of a human acetylcholinesterase promoterreporter construct in developing neuromuscular junctions of Xenopus embryos. Proc Natl Acad Sci USA 90:2471-2475.

Bo X, Schoepfer R, Burnstock G (2000) Molecular cloning and characterization of a novel ATP P2X receptor subtype from embryonic chick skeletal muscle. J Biol Chem 275:14401-14407.

Boyer JL, Romero-Avila T, Schachter JB, Harden TK (1996) Identification of competitive antagonists of the $\mathrm{P}_{2} \mathrm{Y}_{1}$ receptor. Mol Pharmacol 50:1323-1329.

Bradford MM (1976) A rapid and sensitive method for the quantitation of microgram quantities of protein utilizing the principle of protein-dye binding. Anal Biochem 72:248-254.

Chang DC (1997) Experimental strategies in efficient transfection of mammalian cells: electroporation. Electroporation Methods Mol Biol 62:307-318

Chatel JM, Eichler J, Vallette FM, Bon S, Massoulié J, Grassi J (1994) Two-site immunoradiometric assay of chicken acetylcholinesterase: active and inactive molecular forms in brain and muscle. J Neurochem 63:1111-1118.

Choi RCY, Leung PWY, Dong TTX, Wan DCC, Tsim KWK (1996) Calcitonin gene-related peptide increases the expression of acetylcholinesterase in cultured chick myotubes. Neurosci Lett 217:165-168.

Choi RCY, Yung LY, Dong TTX, Wan DCC, Wong YH, Tsim KWK (1998) The calcitonin gene-related peptide-induced acetylcholinesterase synthesis in cultured chick myotubes is mediated by cyclic AMP. J Neurochem 71:152-160.

Dixon JC, Woods NM, Webb TE, Green AK (2000) Evidence that rat hepatocytes co-express functional $\mathrm{P}_{2} \mathrm{Y}_{1}$ and $\mathrm{P} 2 \mathrm{Y}_{2}$ receptors. $\mathrm{Br} \mathrm{J}$ Pharmacol 129:764-770.

Duclert A, Changeux JP (1995) Acetylcholine receptor gene expression at the developing neuromuscular junction. Physiol Rev 75:339-368.

Eichler J, Silman I (1995) The activity of an endoplasmic reticulumlocalized pool of acetylcholinesterase is modulated by heat shock. J Biol Chem 270:4466-4472.

Ewald DA (1976) Potentiation of postjunctional cholinergic sensitivity of rat diaphragm muscle by high-energy-phosphate adenine nucleotides. J Membr Biol 29:47-65.

Filippov AK, Brown DA, Barnard EA (2000) The P2Y ${ }_{1}$ receptor closes the N-type $\mathrm{Ca}^{2+}$ channel in neurones, with both adenosine triphosphates and diphosphates as potent agonists. $\mathrm{Br} \mathrm{J}$ Pharmacol 129:1063-1066.

Fischbach GD (1972) Synapse formation between dissociated nerve and muscle cells in low density cell cultures. Dev Biol 28:407-429.

Fontaine B, Klarsfeld A, Changeux JP (1987) Calcitonin gene-related peptide and muscle activity regulate acetylcholine receptor $\alpha$-subunit mRNA levels by distinct intracellular pathways. J Cell Biol 105:1337-1342.

Fu WM, Chan YH, Lee KF, Liou JC (1997) Regulation of quantal transmitter secretion by ATP and protein kinase at developing neuromuscular synapses. Eur J Neurosci 9:676-685.

Häggblad J, Heilbronn E (1988) P2-receptor-stimulated phosphoinositide turnover in chick myotubes. FEBS Lett 235:133-136.

Henning RH (1997) Purinoceptors in neuromuscular transmission. Pharmacol Ther 74:115-128.

Hilgenberg L, Yearwood S, Milstein S, Miles K (1996) Neural influence on protein kinase $\mathrm{C}$ isoform expression in skeletal muscle. J Neurosci 16:4994-5003.

Horovitz O, Spitsberg V, Salpeter MM (1989) Regulation of acetylcholine receptor synthesis at the level of translation in rat primary muscle cells. J Cell Biol 108:1817-1822.

Ip FCF, Fu AKY, Tsim KWK, Ip NY (1996) Differential expression of ciliary neurotrophic factor receptor in skeletal muscle of chick and rat after nerve injury. J Neurochem 67:1607-1612.

Israel M, Dunant Y (1998) Acetylcholine release and the cholinergic genomic locus. Mol Neurobiol 16:1-20.

Jasmin BJ, Lee RK, Rotundo RL (1993) Compartmentalization of acetylcholinesterase mRNA and enzyme at the vertebrate neuromuscular junction. Neuron 11:467-477.

Kao JP (1994) Practical aspects of measuring $\left[\mathrm{Ca}^{2+}\right]$ with fluorescent indicators. Methods Cell Biol 40:155-181.

King BF, Townsend-Nicholson A (2000) Recombinant P2Y receptors: the UCL experience. J Auton Nerv Syst 81:164-170.

Kolb HA, Wakelam MJ (1983) Transmitter-like action of ATP on 
patched membranes of cultured myoblasts and myotubes. Nature 303:621-623.

Krejci E, Legay C, Thomine S, Sketelj J, Massoulié J (1999) Differences in expression of acetylcholinesterase and collagen $\mathrm{Q}$ control the distribution and oligomerization of the collagen-tailed forms in fast and slow muscles. J Neurosci 19:10672-10679.

Lai J, Jedrzejczyk J, Pizzey JA, Green D, Barnard EA (1986) Neural control of the forms of acetylcholinesterase in slow mammalian muscles. Nature 321:72-74.

Lu Z, Smith DO (1991) Adenosine 5'triphosphate increases acetylcholine channel opening frequency in rat skeletal muscle. J Physiol (Lond) 436:45-56.

Lustig KD, Shiau AK, Brake AJ, Julius D (1993) Expression cloning of an ATP receptor from mouse neuroblastoma cells. Proc Natl Acad Sci USA 90:5113-5117.

Meyer MP, Clarke JD, Patel K, Townsend-Nicholson A, Burnstock G (1999a) Selective expression of purinoceptor $\mathrm{cP}_{2} \mathrm{Y}_{1}$ suggests a role for nucleotide signalling in development of the chick embryo. Dev Dyn 214:152-158.

Meyer MP, Gröschel-Stewart U, Robson T, Burnstock G (1999b) Expression of two ATP-gated ion channels, P2X5 and P2X6, in developing chick skeletal muscle. Dev Dyn 216:442-449.

Michel RN, Vu CQ, Tetzlaff W, Jasmin BJ (1994) Neural regulation of acetylcholinesterase mRNAs at mammalian neuromuscular synapses. J Cell Biol 127:1061-1069.

Moscoso LM, Chu GC, Gautam M, Noakes PG, Merlie JP, Sanes JR (1995) Synapse-associated expression of an acetylcholine receptorinducing protein, ARIA/heregulin, and its putative receptors, ErbB2 and ErbB3, in developing mammalian muscle. Dev Biol 172:158-169.

Moss SJ, Harkness PC, Mason IJ, Barnard EA, Mudge AW (1991) Evidence that CGRP and cAMP increase transcription of AChR alphasubunit gene, but not of other subunit genes. J Mol Neurosci 3:101-108.

New HV, Mudge AW (1986) Calcitonin gene-related peptide regulates muscle acetylcholine receptor synthesis. Nature 323:809-811.

North RA, Barnard EA (1997) Nucleotide receptors. Curr Opin Neurobiol 7:346-357.

O’Malley JP, Moore CP, Salpeter MM (1997) Stabilization of acetylcholine receptors by exogenous ATP and its reversal by cAMP and calcium. J Cell Biol 138:159-165.

Parr CE, Sullivan DM, Paradiso AM, Lazarowski ER, Burch LH, Olsen JC, Erb L, Weisman GA, Boucher RC, Turner JT (1995) Cloning and expression of a human $\mathrm{P}_{2 \mathrm{U}}$ nucleotide receptor, a target for cystic fibrosis pharmacology. Proc Natl Acad Sci USA 91:3275-3279.

Pitchford S, De Moor K, Glaeser BS (1995) Nerve growth factor stimulates rapid metabolic responses in PC12 cells. Am J Physiol 268:936-943.

Pun S, Tsim KWK (1997) Anti-sense agrin cDNA transfection blocks neuroblastoma cell-induced acetylcholine receptor aggregation when co-cultured with myotubes. Mol Cell Neurosci 10:87-99.

Ralevic V, Burnstock G (1998) Receptors for purines and pyrimidines. Pharmacol Rev 50:413-492.

Redman RS, Silinsky EM (1994) ATP released together with acetylcholine as the mediator of neuromuscular depression at frog motor nerve endings. J Physiol (Lond) 477:117-127.

Rotundo RL (1988) Biogenesis of acetylcholinesterase molecular forms in muscle. Evidence for a rapidly turning over, catalytically inactive precursor pool. J Biol Chem 263:19398-19406.

Ryten M, Hoebertz A, Burnstock G (2001) Sequential expression of three receptor subtypes of extracellular ATP in developing rat skeletal muscle. Dev Dyn 221:331-341.

Sambrook J, Fritsch EF, Maniatis T (1989) Molecular cloning: a laboratory manual, Ed 2. Cold Spring Harbor, NY: Cold Spring Harbor Laboratory.

Sandrock Jr AW, Dryer SE, Rosen KM, Gozani SN, Kramer R, Theill LE, Fischbach GD (1997) Maintenance of acetylcholine receptor number by neuregulins at the neuromuscular junction in vivo. Science 276:599-603.

Sanes JR, Lichtman JW (1999) Development of the vertebrate neuromuscular junction. Annu Rev Neurosci 22:389-442.
Sanes JR, Johnson YR, Kotzbauer PT, Mudd J, Hanley T, Martinou JC, Merlie JP (1991) Selective expression of an acetylcholine receptor-lac $\mathrm{Z}$ transgene in synaptic nuclei of adult muscle fibers. Development 113:1181-1191.

Schaeffer L, Duclert N, Huchet-Dymanus M, Changeux JP (1998) Implication of a multisubunit Ets-related transcription factor in synaptic expression of the nicotinic acetylcholine receptor. EMBO J 17:3078-3090.

Sellers LA, Simon J, Lundahl TS, Cousens DJ, Humphrey PPA, Barnard EA (2001) Adenosine nucleotides acting at the human $\mathrm{P}_{2} \mathrm{Y}_{1}$ receptor stimulate mitogen-activated protein kinases and induce apoptosis. J Biol Chem 276:16379-16390.

Silinsky EM, Redman RS (1996) Synchronous release of ATP and neurotransmitter within milliseconds of a motor nerve impulse in the frog. J Physiol (Lond) 492:815-822.

Silman I, di Giamberardino L, Lyles L, Couraud JY, Barnard EA (1979) Parallel regulation of acetylcholinesterase and pseudocholinesterase in normal, denervated and dystrophic chicken skeletal muscle. Nature 280:160-162.

Simon J, Webb TE, King BF, Burnstock G, Barnard EA (1995) Characterization of a recombinant P2Y purinoceptor. Eur J Pharmacol 291:281-289.

Simon J, Vigne P, Eklund KM, Michel AD, Frelin C, Barnard EA (2001) Activity of adenosine diphosphates and triphosphates on a $\mathrm{P} 2 \mathrm{Y}_{\mathrm{T}}$ receptor in brain capillary endothelial cells. Br J Pharmacol 132:173-182.

Thomas SA, Zawisa MJ, Lin X, Hume RI (1991) A receptor that is highly specific for extracellular ATP in developing chick skeletal muscle in vitro. Br J Pharmacol 103:1963-1969.

Tokuyama Y, Hara M, Jones EMC, Fan Z, Bell GI (1995) Cloning of rat and mouse P2Y receptors. Biochem Biophys Res Commun 211:211-218.

Tsim KW K, Randall WR, Barnard EA (1988) An asymmetric form of muscle acetylcholinesterase contains three subunits types and two enzymatic activities in one molecule. Proc Natl Acad Sci USA 85:1262-1266.

Tsim KWK, Greenberg I, Rimer M, Randall WR, Salpeter MM (1992) Transcripts for $\mathrm{AChR}$ and $\mathrm{AChE}$ show distribution differences in cultured chick muscle cells. J Cell Biol 118:1201-1212.

Tsim KWK, Choi RCY, Dong TTX, Wan DCC (1997) A globular, not asymmetric, form of $\mathrm{AChE}$ is expressed in chick motor neurons: downregulation towards maturity and after denervation. J Neurochem 68:479-487.

Tsu RC, Chan JS, Wong YH (1995) Regulation of multiple effectors by the cloned delta-opioid receptor: stimulation of phospholipase $\mathrm{C}$ and type II adenylyl cyclase. J Neurochem 64:2700-2707.

Webb TE, Simon J, Krishek BJ, Bateson AN, Smart TG, King BF, Burnstock G, Barnard EA (1993) Cloning and functional expression of a brain G-protein-coupled ATP receptor. FEBS Lett 324:219-225.

Webb TE, Henderson D, King BF, Wang S, Simon J, Bateson AN, Burnstock G, Barnard EA (1996) A novel G protein-coupled P2 purinoceptor (P2Y3) activated preferentially by nucleoside. Mol Pharmacol 50:258-265.

Webb TE, Henderson DJ, Roberts JA, Barnard EA (1998) Molecular cloning and characterization of the rat P2Y4 receptor. J Neurochem 71:1348-1357.

Weinberg CB, Hall ZW (1979) Junctional form of acetylcholinesterase restored at nerve-free endplates. Dev Biol 68:631-635.

Wells DG, Zawisa MJ, Hume RI (1995) Changes in responsiveness to extracellular ATP in chick skeletal muscle during development and upon denervation. Dev Biol 172:585-590.

Wu J, Kamimura N, Takeo T, Suga S, Wakui M, Maruyama T, Mikoshiba K (2000) 2-Aminoethoxydiphenyl borate modulates kinetics of intracellular $\mathrm{Ca}^{2+}$ signals mediated by inositol 1,4,5-trisphosphate-sensitive $\mathrm{Ca}^{2+}$ stores in single pancreatic acinar cells of mouse. Mol Pharmacol 58:1368-1374.

Zimmermann H (1999) Two novel families of ectonucleotidases: molecular structures, catalytic properties and a search for function. Trends Pharmacol Sci 20:231-236. 